\title{
Review on crosstalk and common mechanisms of endocrine disruptors: scaffolding to improve PBPK/PD model of EDCs mixture
}

Raju Prasad Sharma, Marta Schuhmacher, Vikas Kumar*

Center of Environmental Food and Toxicological Technology (TecnATox), Departament d'Enginyeria Química, Universitat Rovira i Virgili, Tarragona, Catalonia, Spain

* Corresponding author at: Environmental Engineering Laboratory, Departament d'Enginyeria Química, Universitat Rovira i Virgili, Tarragona, Catalonia, Spain. Tel.: +34977558576 .

E-mail address: vikas.kumar@urv.cat 


\begin{abstract}
Endocrine disruptor compounds (EDCs) are environment chemicals that cause harmful effect through multiple mechanisms, interfering with hormone system resulting in alteration of homeostasis, reproduction and developmental effect. Many of these EDCs have concurrent exposure with crosstalk and common mechanisms which may leads to dynamic interactions. To carry out risk assessment of EDCs' mixture, it is important to know the detailed toxic pathway, crosstalk of receptor and other factors like critical window of exposure. In this review, we summarise the major mechanism of actions of EDCs with the different/same target organs interfering with same/different class of hormone by altering their synthesis, metabolism, binding and cellular action. To show the impact of EDCs on life stage development, a case study on female fertility affecting germ cell is illustrated. Based on this summarised discussion, major groups of EDCs are classified based on their target organ, mode of action and potential risk. Finally, a conceptual model of pharmacodynamics interaction is proposed to integrate the crosstalk and common mechanism that modulates estrogen into the predictive mixture dosimetry model with dynamic interaction of mixture. This review will provide new insight for EDCs' risk assessment and can be used to develop next generation PBPK/PD models for EDCs' mixture analysis.
\end{abstract}

Keywords: Endocrine disruptor compounds (EDCs); toxicity mechanism; mixture interaction; common mechanism; crosstalk; PBPK/PD models.

\title{
List of Abbreviations
}

3MC: 3-methylcholanthrene

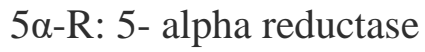

ACTH: adrenocorticotropic hormone

Ahr: aryl hydrocarbon receptor

Ahrr: aryl hydrocarbon receptor repressor

AKT: serine/threonine kinase

AMH: anti-mullerian hormone

AMPO: ammonium Perflurooctane

ARC: arucate cell

Arnt: aryl nuclear translocator
AVPV: anteroventral periventricular nucleus

BAX: BCL2 associated protein

BCL2: apoptosis regulator

BMP: bone morphogenetic protein

BPA: bisphenol A

CAR: constitutive androstane receptor

CREB: cAMP response-elementbinding protein

Cx43: connexin X 43

CYP1A1: cytochrome enzyme A

CYP1B1: cytochrome enzyme B 
CYP19A: aromatase enzyme

CYP450scc: cytochrome p450 side chain cleavage

DBT: dibutylin

DEHP: diethylhexyl phthalate

DTCs: dithioarbamate chemicals

ERE: estrogen response element

E2: estrogen

FAK: focal adhesion kinase

Fas- membrane protein

FasL: fas ligand

Figla: factor in the germline alpha

FOXO3: forkhead box proteins

FSH: follicle stimulating hormone

GATA4: transcription factor

GDF: growth differentiation factor

$\mathrm{GH}$ : growth hormone

GJ: gap junction

GJA1: gap junction alpha protein

GnRH: gonadotropin releasing hormone

GVBD: germinal vesicle migration and breakdown

HAT: histone acetyl-transferase

HPA- hypothalamus pituitary adrenal axis

HDAC: histone deacetylases

HMT: histone methyl transferase
HPOA: hypothalamus preoptic nucleus

HSDs: hydroxysteroid dehydrogenases

HSP90: heat shock protein 90

IGF-1: insulin growth factor

IGFR: insulin growth factor recptor

Igf2r: insulin like growth factor 2

INH: inhibin

IP3-DAG: inositol triphosphatediacyglycerol

LH: luteinizing hormone

LHR: luteinizing hormone receptor

LHX8: LIM homeobox 8

LXR: liver X receptor

LXR: liver X receptor

MAPK: mitogen activated protein kinase

MEHP: mono (2-ethylhexyl) phthalate

MMP2: metalloproteinase 2

NCoA: nuclear coactivator

NCoR: nuclear corepressor

NF-kB: nuclear factor $\mathrm{k} B$

NOBOX: newborn ovary homeobox

NR: notch receptor

p160/SRC: steroid receptor coactivator

P23: protein 23 
P4: progesterone

PR: progesterone receptor

PBPK/PD : Physiological based

Pharmacokinetics/Pharmacodynami

cs modeling

PBR: peripheral type

Benzodiazepine receptor

PCBs: polychlorinated biphenyl

PCDDs: polychlorinated

dibenzodioxins

Peg3: paternal express gene 3

PEPCK: phosphoenolpyruvate carboxykinase

PFASs: poly-fluorinated alkyl substances

PI3: phosphatidylinositol 3-kinase

PMG: primordial germ cell

PPARs: peroxisome proliferator activated receptors

PTEN: phosphatase and tensin homolog

PXR: pregnane $\mathrm{X}$ receptor

RIP140: receptor interacting protein

ROS: reactive oxygen species

RXR: retinoid X receptor

SDM: sexual dimorphism

SF:1-steroidogenesis factor 1

SHBG: steroid hormone binding globulin
SMRT: silencing mediator for retinoid or thyroid-hormone receptors

Sohlh2: spermatogenesis and oogenesis helix-loop-helix 2

SREBP 2: sterol Response Element Binding Protein 2

SREBP1c : sterol Response Element Binding Protein 1c

StAR: steroid acute regulatory protein

SUG 1: suppressor for gal 1

SULTs: sulphotransferase enzyme

TAT: tyrosine aminotransferase

TBG: thyroid binding globulin

TBT: tributyltin

TCDD: 2,3,7,8-tetrachlorodibenzop-dioxin

TCPOBOP : 1, 4-bis- [2-(3, 5,dichloropyridyloxy)] benzene

TH: thyroid hormone

TJ: tight junction

TNF $\alpha$ : tumor necrosis factor $\alpha$

TPT: triphenyltin

TRAIL: TNF:related

apoptosis:inducing ligand

TRs: thyroid receptor

TSPO: translocator protein

UDPGT1A1: uridine diphosphate glucuronic transferase enzyme 
VCL: vocal adhesion molecule

vinculin

VEGF: vascular endothelial growth

factor

VTG: vitellogenin

XAP2: X-associated protein 2

ZO-1: zonula occludens-1 


\section{Introduction}

U.S. EPA define endocrine disruptor compounds (EDCs) as exogenous agents that interfere with synthesis, secretion, transport, metabolism, binding action, or elimination of natural blood-borne hormones that are present in the body and are responsible for homeostasis, reproduction, and developmental process (Kavlock et al., 1996). The WHO extended this definition linking EDCs to adverse health outcomes in an intact organism, or its progeny or subpopulation (WHO, 2002). The Endocrine Society describe EDCs as chemicals that interferes with any aspect of hormone action (Gore et al., 2014). EDCs can be found in daily uses products such as detergents, food cans, plastic bottles, children toys, flame retardants, cosmetics, and processed food (Clarkson, 1995; Rudel and Perovich, 2010). The EDCs interfere with hormone kinetics and its dynamic causing alteration in hormone level or expression of hormone responsive element (Crisp et al., 1998).

The aim of hormones is to execute its specific task on specific time with specific amount. There are many studies which link hormone alteration to different diseases outcomes. For example, low testosterone and SHBG level are the early biomarker for the risk of metabolic syndrome (Kupelian et al., 2006); alteration of E2, ER $\alpha$, PR and the aromatase enzyme are strongly linked with endometriosis and infertility (Kitawaki et al., 2002); alteration in FSH, LH, inhibin B, and testosterone level is associated with decrease sperm quality (Meeker et al., 2006). Earlier assumption that EDCs and hormones would yield the same responses in different cell lines or tissues was found wrong. Now it is well known that EDCs have cell and tissues-specific responses (Lackey et al., 2001). Even at very low concentration, EDCs can produce significant endocrine disruptive action (Vom Saal and Hughs., 2005; Vandenberg et al., 2012) which challenges classical dose response curve at significantly high doses. Further, EDCs show disparate response at different life-stage dependent physiological concentrations of hormone, challenging current risk assessments methodologies which are not in consonance with life-stage changes (Welshons et al., 2003; Vandenberg et al., 2013). For instance, a study from Ohtake et al., (2003) showed that EDCs can produce contrary response based on physiological stage of prepubertal and pubertal. The interference of EDCs with developmental stages (prenatal-postnatal-early childhoodadulthood) and reproductive stages showed time of exposure as an important factor to determine its potency as well as developmental effect (Haimes, 2009; Gore et al., 2014). For example, there are strong relationship of EDCs exposure affecting HPG axis system and alteration in the age of female puberty showing developmental effect (Wang et al., 2005; Euling et al., 2008). The biological marker like enzyme expression and hormone level can help in assessing developmental risk by knowing detail mode of action of EDCs (Rockett et al., 2003).

Human are subject to continuous and simultaneous exposure to EDCs via its surrounding environment and bioaccumulation becomes inevitable in many cases, which might cause permanent damage following physiological adaptation failure (Vandenberg et al., 2013). Several studies showed that chemicals at individual level 
have no observed effect level (NOEL), when exposed simultaneously as a mixture shows adverse effect disproving the concept of NOEL and taking more attention towards mixture studies (Rajapakse et al., 2002; Silva et al., 2002). The successive use of PBPK model in field of toxicology is commendable since it has great advantage of predicting internal tissue dose by integrating experimental data (both in vivo and in vitro) and extrapolation across species (Caldwell et al., 2012). However, level of biomarker of exposure (internal tissue dose) is, in many case, not sufficient to predict the toxicity of chemicals and additionally, when the effect of chemical mixture for certain response deemed to have toxicodynamic interaction. . Moreover, many biological response is the convergence of multiple signaling pathways, eventually become vulnerable to multiple targets of EDCs. Incorporation of the relationship between the exposure at the sites of action and the response generated can extend PBPK model to PBPK/PD (Nestorov, 2007). The objective of this review (summarized in Figure 1) is to understand the mechanism of actions of EDCs which includes interaction of chemicals with molecular receptor, enzymes, proteins, gene regulatory mechanism or epigenetic process thus affecting biological system, including window of exposure. Besides, this review also investigates the normal endogenous pathway of hormone sidewise to better understand the physiology dependent EDCs' action. The last part of the review includes an example showing common as well as cross talk mechanism of EDCs mixture affecting estrogen kinetics. Improved understanding of common as well as crosstalk mode of action and categorization of chemical based on similar adverse outcomes may provide better scaffolding for integration of pharmacokinetics and pharmacodynamics into predictive mixture toxicological model of EDCs.

\section{Molecular mechanism of EDCs on the endocrine system}

In general, individual EDCs can affect the endocrine system accounting their synthesis to metabolism; receptor mediated action, various signaling pathway and crosstalk signaling between receptors. In this section, a summarized review of EDCs' effects on major hormones namely thyroid and steroids (corticosteroid and gonadal) is provided.

\subsection{EDCs affecting thyroid hormone}

Thyroid hormones (THs) are one of the integral parts of hormone system required for normal brain and somatic development. It has been seen that EDCs can disrupts the function of thyroid system possibly through multiple mechanisms such as synthesis, transports, and the receptors like TR, Ahr, CAR, PPAR and RXR, mediated function for subsequent action and metabolism of hormone. Various chemicals affect homeostasis of hormone including Perchlorates, PCBs, PCDDs and PCDFs (Zoeller, 2010). Perchlorates inhibits uptake of iodide into thyroid follicle (Clewell et al., 2004). PCBs, PCDDs and PCDFs competitively bind with transthyretin impair transportation (Lans et al., 1994) and their affinity towards the Ahr receptor leads to increase metabolism of hormones (Poland and Knutson, 1982).

The toxicology pathway of EDCs via Ahr is shown in Figure 2; where Ahr receptor is present in the cytosol in conjugation with subunits like chaperon protein HSP90, 
regulatory protein p23 and immunophilin like protein XAP2 ( Perdew, 1988; Kazlauskas et al., 1999; Petrulis et al., 2000). Subsequently binding of EDCs with Ahr form complex followed by dissociation of Hsp90, P23 and XAP2 and translocation into the nucleus. In the nucleus, Ahr forms heterodimer complex with Arnt which then bind with XRE causing increase in expression of CYP1A1 and UDPGT1A; and finally leads to increase in metabolism of thyroid hormone (Hankinson, 1994; Birgelen et al., 1995). Simultaneously, there is feedback inhibition of Ahr transactivation by Ahrr (Mimura et al, 1999). Qatanani et al., (2005) reported that EDCs affinity towards CAR, can be other possible mechanism of metabolism of thyroid, that alters the UGTs and SULT mediated glucuronidation and sulfation of $\mathrm{TH}$, respectively.

BPA has been reported as anti-thyroid agent that is mediated via multiple molecular mechanisms, mainly involved in altering receptor gene expression and dynamic stability. It decreases the TR $\alpha$, TR $\beta$ mRNAs level and subsequently suppress RXR gene expression which is a heterodimer partner of TR. Additionally, it can also inhibits the binding of T3 to TR by recruiting N-CoR (Moriyama et al., 2002; Iwamuro et al., 2006). The isoform of TR remains in dynamically equilibrium state between inactive and active form to maintain the physiological action. The binding of EDCs with TR favors its inactive isoform (see Figure 3) via recruitment of (N-CoR). Subsequently, increase in HDAC, HMT, and HDM level induces the repression of target gene making TR inactive. In contrast, binding of thyroid to TR induces conformation changes and recruit coactivators of $\mathrm{p} 160 / \mathrm{SRC}$ (steroid receptor coactivator). These coactivators have inherent histone acetylase activity that recruits complex like histone arginine methyltransferase (HMT), HAT and chromatin remodeling complex and form active homodimer or heterodimer complex with RXR (Ahuja et al., 2003; Yoon et al., 2005; Flamant et al., 2007). Juge-Aubry et al., (1995) mentioned that RXR was the common partner for both TRs and PPARs to form active heterodimers. Hence, the EDCs having affinity for PPARs or RXR could affect thyroid activity through crosstalk mechanism.

\subsection{EDCs affecting steroid hormone}

\subsubsection{EDCs affecting corticosteroid hormone}

Among corticosteroid hormones, glucocorticoids such as cortisol is produced in response to stress and is an integral part of HPA axis involved in cellular homeostasis and different metabolic processes. The enzymes that are responsible for the biosynthesis of these hormones mainly involved CYPs, HSDs and steroid reductases (Miller, 1988). The molecular mechanisms involved in biosynthesis are transfer of cholesterol to inner mitochondrial membrane by regulatory protein StAR (Manna and Stocco, 2005) and conversion of cholesterol to pregnenolone by CYP11A or CYP450scc (Parker and Schimmer, 1995; Manna and Stocco, 2005). Subsequent action of CYP17A and HSDs enzyme accomplish the glucocorticoid synthesis.

The interconversion of cortisol (active) to cortisone (inactive) involves two isoform of $11 \beta$-HSD namely $11 \beta$-HSD1 and 11 $\beta$-HSD2 (Krozowski et al., 1999). This interconversion plays an important role in regulating central adiposity (Stewart et al., 1999) and protecting developing fetus from glucocorticoid excess (Krozowski et al., 
1995). The EDCs like PFASs, TBT, TPT and dithiocarbmates inhibit $11 \beta$-HSD2 isoform (Atanasov et al., 2003; Ohshima et al., 2005; Zhao et al., 2011), and their exposure during pregnancy stage has been found to alter normal fetus development. Wang et al., (2012) mentioned the role of BPA on increased expression of 11 $\beta$-HSD1, results in higher cortisol level, increase lipoprotein lipase and PPAR- $\gamma$ which lead to increased adipocyte differentiation. The expression of PEPCK and TAT, well characterised metabolic response of glucocorticoid, was shown to be inhibited by DBT which decrease affinity of glucocorticoid towards its receptor (Gumy et al., 2008). Furthermore, one of the metabolic pathways of steroid involves PXR, a xenobiotic receptor which regulates CYP3A expression. Chemicals like phthalic acid and nonylphenol inhibit PXR degradation, thus enhancing CYP3A expression which leads to alteration in metabolism of steroid hormones (Masuyama et al., 2000, 2002).

\subsubsection{EDCs affecting gonadal hormone}

The effect of EDCs on human reproductive system has been linked with infertility, mediated through diverse mechanism that includes: altering gonadal steroidogenesis, affecting HPA axis and feed-back mechanism, altering receptor biology, crosstalk of receptor signaling, and direct organ toxicity. For the steroidogenesis, cholesterol is the main precursor which can be affected by the EDCs that alters receptor like PPAR $\alpha$ and PXR which regulates transporter protein, such as Translocator protein (TSPO) or peripheral type Benzodiazepine receptor (PBR) that transport cholesterol from cytosol to the mitochondria (Hauet et al., 2005; Fan and Papadopoulos, 2012) and the metabolism of cholesterol by regulating transcription of rat CYP7A1 (cholesterol $7 \alpha-$ hydroxylase) gene (Marrapodi and Chiang, 2000; Staudinger et al., 2001; Li et al., 2011).

Moreover, the involvement of many supplementary pathways initiated via different receptor likes GHR, IGF-1 and (RXR/ TR) which regulate the function of steroidogenic enzyme and the affinity of EDCs towards these receptors, makes toxicity mechanism more complex (Chandrashekar and Bartke, 1993; Xu et al., 1995; Hull and Harvey, 2000; Manna et al., 2001; N'Diaye et al., 2002). In addition to that, the central system HPG axis which regulates gonadal cell plays an important role in normal reproductive development process. At the hypothalamic level, kisspeptin neurons express both, ligand KiSS-1 and its receptor GPR54 that regulates the release of GnRH in pituitary which in turn control expression of FSHR and LHR in gonadal cell. The kisspeptin neurons also express ER- $\alpha$ which involves in feedback inhibition of GnRH in response to estrogen stimulation. This feed forward mechanism holds important role during normal fertility cycle of pre-ovulatory to ovulatory phase (Roseweir and Millar, 2009; Silveira et al., 2010; Hameed et al., 2011). It has been shown in rodent models that exposure of BPA affects HPG axis with different mechanism depending on life stage of exposure; at prepubertal stage damages kisspeptin neuron and at puberty stage alters ERamRNA expression (Ceccarelli et al., 2007; Patisaul et al., 2009). Xi et al., (2011) showed that the involvement of BPA on transcript levels of GnRH and FSH in the male and female pup via altering Kiss-1 mRNA expressions further supports the notion of multilevel mechanism of EDCs. 
Boberg et al., (2008) reported that exposure to phthalates causes the reduction of anogenital distance, sign of male infertility, via the reduction of leptin level which supports the concept of leptin regulation of LH and FSH via leptin-kisspeptin-GnRH pathway (Neurons et al., 1999; Luque et al., 2007). The Leptin synthesis was also found to be inhibited by cadmium exposure (Stasenko et al., 2010). In addition to that the local gonadal enzyme CYP19A (aromatase) catalyses the androgen to estrogen conversion to balance androgen-estrogen level which is the prerequisite for the normal fertility in both male and female (Simpson et al. 1994). Several studies have been reported TBT inhibition of aromatase enzyme in granulosa cell results in imposex affecting fertility (Saitoh et al. 2001; Heidrich et al. 2001). Many studies have shown the EDCs dual action regards to estrogen level (Ohtake et al., 2003, 2007). For instance dioxins exposure at prepubertal stage, shows estrogenic activity via enhancing binding of ER $\alpha$ to ERE. However at pubertal stage, dioxin-receptor complex repressE2 bound ER function leading to antiestrogenic effects (Ohtake et al., 2003). In another study, Ohtake et al., (2007) reported the antiestrogenic activity of EDCs like TCDD and 3MC via activation of E3 ubiquitin ligase pathway that results in degradation of ER $\alpha$ and Ahr. In contrast to antiestrogenic activity, certain EDCs increase bioavailability of estrogens via inhibiting principle of estrogen sulphotransferase (SULT1E1) enzyme which causes inactivation of E2 (Kester et al., 2002).

The male sex hormone testosterone biosynthesis has been shown to be affected by TCDD and PFOA via different mechanism of action that involves altering signaling pathway, regulating expression of enzyme or direct inhibition of enzyme involved in steroidogenesis (Fukuzawa et al., 2004; Lai et al., 2005a; Shi et al., 2009; Zhao et al., 2010; Wan et al., 2011). Saunders et al., (1997) reported that exposure of pregnant mother to octyl phenol, decreases the level of testosterone in the fetal rat testis via altering the expression of CYP17 $\alpha$-hydroxylase/C17-20 lyase and steroidogenesis factor 1 (SF-1) leading to development reproductive disorder. The local hormone like AMH responsible for sexual differentiation in fetus during embryogenesis also nurture the testosterone by increasing prenatal proliferation of leydig cell and maintain the prepubertal stage in male. In parallel, developmental exposure of BPA and PCBs are linked to decrease level of AMH, LHR ,17 $\beta$ HSD3 and reduced aromatase activity in hypothalamus, affecting sexual maturation (Lee and Donahoe, 1993; Hany et al., 1999; Rey et al., 2003; Nanjappa et al., 2012). In addition to that, TBT or TPT are found to inhibit both $5 \alpha-\mathrm{R} 1$ and $5 \alpha-\mathrm{R} 2$ isozymes, responsible for production of active androgen (Svechnikov et al., 2010), affecting male sexual characterization (Doering et al. 2002). Castro et al., (2013) found similar results for BPA, reporting inhibition of both $5 \alpha$ reductases at their synthesis level. Simultaneous exposure of both chemicals (TBT and BPA) could lead to more impact on male fertility. Moreover, exposure to EDCs has shown to induce reproductive toxicity by damaging the integrity of blood testes barrier (BTB) in sertoli cell that causes impairment in spermatogenesis (Cheng et al., 2011).

The EDCs like BPA, PFOS, DEHP and cadmium induced reproductive toxicity is found to be mediated via altering MAPK, PI3K/c-Src/FAK, p38 MAPK and ROS signaling pathway leading to alteration in synthesis and metabolism of different protein likes 
occludin, ZO-1, Cx43 and catenin affecting BTB integrity (Chitra et al., 2003; Sobarzo et al., 2006; Li et al., 2009; Siu et al., 2009; Cheng et al., 2011; Wong and Cheng, 2011; Qiu et al., 2013; Ansoumane et al., 2014). It has also been found that Sertoli cells have functional Ahr, responsible for TCDD dose-dependent toxicity that alters mRNA level of testin, aromatase, sertolin and MIS which are important for germ cell development (Lai etal. 2005). Phthalates are well characterized as reproductive toxic agents that causes apoptosis of germ cell by activating caspase pathway which includes: activation of fas by increased expression of fasl ( Richburg and Boekelheide, 1996; Lee et al., 1999; Richburg et al., 1999; Koji et al., 2001), accumulation of lipid in somatic cells via increased LXR $\alpha$ mRNA expression (Muczynski et al., 2012) and downregulation of both GJA1 and vocal adhesion molecule vinculin (VCL) by increasing MMP2(Yao et al., 2012). Subsequently, activation of NFkB via increase expression of TRAILR1(DRP4) and TRAIL-R2 (DRP5) leads to increase apoptosis of germ cell without modification of their proliferation (Giammona 2002; Lambrot et al. 2009). Figure 4 shows the mechanism of phthalates causing germ cell apoptosis in fetus.

\section{Effect of EDCs in different window of exposure: case study on female fertility}

It has been shown that EDCs have disparate response at different life-stage, depending on the physiological concentrations of hormone (Ohtake et al., 2003). However, primary concerns for female fertility are exposure to EDCs at prenatal and postnatal stages, which are at higher risk of reproductive failure as well as metabolic disorder and hormonal disorders in their later life. EDCs can alter normal cellular and tissue development and function through their interference in developmental programming of body (Schug et al., 2011). To study the life stage risk assessment on fertility, it is very important to know the detailed mechanism behind development of germ cell into mature oocyte. This involves complex and sequential biological network of signaling pathway.

\subsection{Physiology of development of germ cell into mature oocyte}

During epigenetic reprogramming of germ cell, at the very first step, involves DNA demethylation to regain differentiation totipotency which subsequently undergoes mitotic division without completing cytokinesis to the formation of germ cell cyst (Pepling and Spradling, 1998). Before birth, germ cells go through meiosis and arrest in diplotene phase of meiotic prophase until puberty comes. Meanwhile germ cell cyst undergoes apoptosis followed by surrounding of pregranulosa cell forming primordial follicles (Borum, 1961; Pepling and Spradling, 2001). After forming primordial follicles, estrogens play a role in maintaining these follicles pool by inhibiting oocyte nest breakdown through inhibition of BCL-2 gene transcription via both genomic and nongenomic pathway ( Perillo et al., 2000; Chen et al., 2007, 2009).

Moreover, additional pathways are also involved for the regulation of primordial follicles which involves Notch signaling, and KIT-KL pathway. Notch signaling activation involves expression of Jagged1 and Jagged2 (ligand), in germ cells and Notch2 (ligand), in granulosa cells to form a receptor ligand complex. The proteolytic 
cleavage of this complex by $\gamma$-secretase produces intracellular domain of Notch (NICD) which translocate into the nucleus and interacts with the CSL family to form the complex. This complex recruits histone acetylase and regulates the expression of LHX8, NOBOX, Figla and Sohlh2 involved in formation of primordial follicles (Baron, 2003; Shih and Wang, 2007; Chen et al., 2014; Vanorny et al., 2014). KIT receptor expressed in oocyte and the KIT ligand is present in both oocyte and primordial follicle, help in initiation and progression of follicular development (Parrott and Skinner, 1999) via the activation of the MAPK pathway (Jones and Pepling, 2013). GDF9 increases kit ligand mRNA expression and thus promotes the progression of primary follicle development (Nilsson and Skinner, 2002). BMP4 and BMP7 play a major role in survival and growth of primordial follicle to primary follicle by decreasing KL and TGF- $\alpha$ expression respectively (Nilsson and Skinner, 2003; Lee et al., 2004). Cx43 expressed in both cumulus and granulosa cell play an important role in paracrine signalling and gap junctional intercellular communication between cumulus cell and follicular cell providing follicular development and oocyte quality (Ackert et al., 2001; Gittens et al., 2005; Wang et al., 2009). BMP4, BMP7 and BMP15 downregulate Cx43 in human granulosa cell via smad pathway and thus decreases the gap junctional intercellular communication leading to prevention of premature luteinization ( Chang et al., 2013; H. M. Chang et al., 2014).

The interplay between paracrine hormones is very important for the transition of primordial follicle to primary follicle to become a mature oocyte. AMH inhibits primordial follicles to enter the pool of growing follicles (Durlinger et al., 1999) by decreasing expression of inhibin (Themmen and Themmen, 2009). Billiar et al., (2003) also reported the inhibition of expression of inhibin by the estrogen in pregranulosa and oocyte. Thus, estrogens play an important role in regulating inhibin and follicular development. The TGF- $\beta$ signaling involves GATA-4 and Smad-3 coordination for activation the inhibin (Anttonen et al., 2006). Androgens play an important role in follicle development via increasing expression of, FOXO-3, GDF9 through PI3/AKT pathway, and, KIT/KL through genomic pathway during primordial follicle to primary follicle stage. Specifically, during development of primary follicle to antral stage, it inhibits proapoptotic proteins and stimulates FSH mRNA expression, cAMP and p450scc through both genomic and non genomic i.e. MAPK/ERK pathway which in turn stimulates aromatase enzyme (Prizant et al., 2014). FSH stimulates LHR expression, (Richards et al., 1976) inhibin B production (Lee et al., 1982), and induces aromatase activity in the granulosa cells, results in more estradiol level (Short, 1962; Richards et al., 1976; Hillier et al., 1981). Moreover, most FSH sensitive called dominant follicle produces the highest levels of inhibin B and estradiol which in turn causes feedback inhibition of FSH production, required for growth of remnant follicles (Hirshfield and Midgley, 1978). After selection of dominant follicle, subsequently progesterone causes germinal vesicle migration and breakdown (GVBD) for resumption of meiosis at puberty by activating p53 and E2F transcription factor 1 (Garcia-reyero et al., 2015) leading to ovulation. The fertilization of ovum results in formation of zygote and matured follicle after releasing ovum called lutein cell which secretes VEGF. It 
prolongs the lutein cell function that maintains the progesterone level important for pregnancy development. VEGF function is regulated via PPAR $\gamma$ (Fraser et al., 2000; Kaczmarek et al., 2005).

\subsection{EDCs interaction with target molecules and its pathway}

Exposure to Lindane, PCBs and PAHs to embryo has been linked with premature reproductive ageing by causing the apoptosis of germ cell through different pathways such as activation of caspase- 3 and poly-ADP ribose polymerase cleavage (PPAR) by Lindane and activation of BAX via Ahr by PAHs (Ronnback and de Rooij, 1994; Matikainen et al., 2002; La Sala et al., 2009; Kee et al., 2010). Phthalates exposure induce primordial follicle recruitment via activation of PI3K/AKT pathway, resulting in premature ovarian follicle and infertility (Hannon et al., 2014). Moreover Castrillon et al., (2003) study supported that FOXO3A knock out mouse, leading to premature oocyte follicle which is regulated by the PTEN/PI3K/AKT pathway. Both, Phthalates and BPA lowers the expression of LHX8, Nobox, Figla, and Sohlh2, involved in oocyte survival and follicular recruitment to form primordial follicle. In addition to this both compounds alter epigenetic reprogramming of Lhx8 by preventing DNA demethylation (Zhang et al., 2012, 2014). However, BPA shows multiple mechanism of action, altering steroidogenesis and proliferation of granulosa cell such as: induction of PPAR $\gamma$ causing downregulation of FSH-stimulated IGF-1, SF-1, GATA4, aromatase, and E2 (Kwintkiewicz et al., 2010), decreases both StAR and P450scc mRNA impairing hormone production in the antral follicles (Peretz et al., 2011), activates nongenomic pathway of estrogen via PKA and PKG pathway associated with phosphorylation of transcription factor CREB and the cell cycle regulator Rb (Bouskine et al., 2009). Additionally, BPA delayed maturation of oocyte by inhibiting resumption of meiosis via altering ER expression, following hypomethylation of imprinted gene Igf2r, Peg3, and GVBD, (Chao et al., 2012). On the other hand, other EDCs like Methoxychlor inhibits follicular development by stimulating AMH (Uzumcu et al., 2006). This is further supported by the study of impairmaint of follicular development in neonates on exposure of estradiol benzoate found to be via increased expression of AMH (Ikeda et al., 2002). Moreover, Nagel et al., (1999) shown that BPA even at very low dose can affect sexual dimorphism of infants via its estrogenic action in brain. whereas in normal, prenatal estrogen form complex with Alpha fetoprotein, protecting the female brain from defeminization and masculinization (Bakker et al., 2006).

EDCs contamination in the human follicular micro-environment is associated with a lower chance of an oocyte to develop into a top-quality embryo, leading to lowering in fertilization rate (Petro et al., 2012). For instance, PCBs exposure affects oocyte quality and competence via multiple mechanisms; alters microtubule organization, mRNA polyadenylation levels, redistribution of cortical granules, mitochondrial disorganization, leading to polyspermy and affecting in transcript stability. It can also directly cause cumulus cell apoptosis which is communicator cell between oocyte and follicle mediated via Ahr signaling (Gandolfi et al., 2002; Brevini et al., 2005; Pocar et al., 2006). MEHP an endocrine disruptor inhibit embryonic genome activation (EGA) 
initiation and maternal-effect genes resulting in the suppression of maternal-toembryonic transition by generating ROS (Chu et al., 2013).

Figure 5 summarizes the life stage development of germ cell to oocyte and the possible targets of EDCs. In his turn, Figure 6 explains the complex signaling pathway for life stage development of germ cell maturation to oocyte.

\section{Grouping strategy and conceptual model of PBPK/PD in assessing risk for chemical mixture}

\subsection{Grouping strategy}

There are numerous classification of EDCs reported in the literature based on different criteria like pathway of exposure, level of exposure, target hormones, adverse effects, and diseases outcomes (Caserta et al., 2008; Wuttke et al., 2010; Craig et al., 2011; Schug et al., 2011; Casals-Casas and Desvergne, 2011; Vandenberg et al., 2012; Hampl et al., 2014). Ongoing discussion of the risk assessment for chemical mixture (EFSA, 2013) needs new grouping strategy which clusters EDCs based on their similar adverse outcomes via independent, cross talk and common interaction mechanism involving multiple organs and hormones. Similar prerequisite for cumulative risk assessment of chemical mixtures has been cited by EFSA (Kortenkamp, 2007; EFSA, 2013). This type of grouping strategy (based on similar adverse outcomes) could also help in making decision on whether to go for dose addition or response addition method for mixture interaction study (Culleres et al., 2008). A detail discussion on classification is beyond the scope of this review. However, a detail classification for selected chemicals is provided in Annex Table 1. Classification of EDCs proposed in this review is based on target organs, hormones, biomolecule (MOA) and adverse outcomes, which can provides basis for grouping strategy for mixture modelling. Proposed grouping strategy has been illustrated in Figure 7 by giving a small example of four chemicals (BPA, TCDD, Phthalates and PFOS). Some of these chemicals are categorized in one group for mixture study based on their similar adverse outcome including targets organs like thyroid gland and sertoli cell, and in another group with dissimilar mode of action (crosstalk) producing common adverse effect of altering thyroid action and decreasing sperm count, respectively. Similar grouping strategy has been followed in Figure.9 for the chemicals affecting female fertility.

\subsection{Conceptual model of PBPK/PD}

A chemical can alter hormone actions by targeting at the level of epigenetics-geneenzyme/receptor followed by endogenous intracellular signaling pathway (Grün and Blumberg, 2006; Cruz et al., 2014). Therefore, the mixture of chemicals producing similar adverse outcomes via entirely different mode of action can be categorized in one group in order to analyze the combination effect. Furthermore, timing and level of exposure is also an important parameter which can make adverse effect temporary or permanent and has to be included when assessing risk ( Fenton, 2006; Buck Louis et al., 2008; Palanza et al., 2016). Based on methodologies (Figure 7), we proposed a 
conceptual model which brings the fate and the consequence of chemical mixture in the integrated risk assessment framework of exposome-internal exposure-biological effect to the adverse outcome (Figure 8).

At the dynamic level, integration of individual mechanisms to the dynamic interactions of mixture for assessing risk is still debatable (Lambert and Lipscomb, 2007; EFSA, 2013; Karri et al., 2016). Figure 9 shows a small example of hypothetical schematic model that integrates individual mode of actions based on their target molecule in a system based approach. It includes common, crosstalk as well as dissimilar mode of action based on their targets of common outcome. For instance, the dioxin-like chemicals, DBP, BPA, TOP and PAH-OH alter the estrogen action at different levels of peripheral as well as central mechanism. Their major targets include kisspeptin neuron, CYP19A (aromatase), SHBG, ER, Ahr, ERE CYPA1 and CYPB1 affecting estrogen and progesterone feed forward mechanism, consequently leading to risk of infertility. In fact, EDCs like DBP, BPA and TOP show similar mode of action via targeting CYP19A and SHBG. Dioxin-like substances exhibit dual role such as "antiestrogenic" via Ahr dependent CYPB1 mechanism and "estrogenic" via estrogen receptor showing crosstalk between ER and Ahr. PAH-OH and BPA can interact with other dioxin-like substances in respect to their targets via crosstalk between Ahr and SULTE1 altering metabolism of estrogen. BPA, PAH-OH and other dioxin-like substance are able to simultaneously interfere with endocrine system through multiple mechanisms. The mixture effects of these chemicals in system based model can be possible by considering estrogen, progesterone and ERE, as end point biomarker of infertility, and integrating available individual toxicological profile data into a dynamic mixture model of EDCs (PBPK/PD).

\section{Summary \& future perspective}

We have summarized the effects of endocrine disruptors on thyroid, adrenal, and sex hormones accounting their effects on synthesis, metabolisms and actions. Mixture of chemicals can simultaneously interfere with multiple endocrine pathways via multiple mechanisms making mixture effect more pronounced than individual. The EDCs acting on certain hormone via multiple mechanisms (central or peripheral) can be grouped for risk assessment of mixture of chemicals, according with their similar adverse outcomes.

Most of the EDCs have non monotonic dose-response curve which is the major drawback when establishing a relationship between the exposure kinetics and elicited response (Vandenberg et al., 2012; Beausoleil et al., 2013; Yang et al., 2016). Additional challenges like multiple mechanisms, delayed response ( time lag between exposure to adverse outcomes), dynamic interaction involving crosstalk and common mechanism, and transgenerational effect added more complexity in the quantitative risk assessment (Maffini et al., 2006; Matthiessen and Johnson, 2007; Rubin, 2011; Fowler et al., 2012).

However, understanding molecular mechanism of interaction of chemicals with endogenous molecule or pathway can explain the variability among chemicals for the 
same adverse effect (Filby et al., 2007). For instance, BPA shows complex doseresponse curve in concentration dependent model which could be explained by the fact that it alters the gene expression through genomic as well as nongenomic pathway (Takayanagi et al., 2006; Vandenberg et al., 2009; Vandenberg, 2014). Similarly, dioxin-like substance shows dual response that can be explained by availability of endogenous hormone and their action. The potential dynamic interaction may leads to change in the response curve in case of mixture of chemical, which can be explained by understanding different type of mechanistic interactions like crosstalk or similar or dissimilar MOAs as it has been explained in this review. Similarly, understanding latency of exposure (i.e. lag time between exposure and response) is important as in case of infertility disorder, which can only be detected after a certain age though exposure occurs at early stage of life.

Lots of experiments have been done on individual EDCs but it is very hard to find mixture level studies. Selecting chemicals and then optimizing dose for selected mixture for carrying animal experiment is another difficult task. To know the potency of individual chemical in mixture due to their complex interaction behavior at different levels, require large combinatorial experimental design. Normally this kind of experiments requires large number of animals which will be against the current ethical guideline of risk assessment (EU, 2010). However, tremendous development in invitro, in-silico techniques and emerging area like omics, generating lots of toxicological data leads to new era of quantitative risk assessment (Knudsen et al., 2015).

Incorporation of individual mechanism of chemicals into mixture model provides platform for assessment of combined risk produced by mixture of chemicals. Understanding individual mechanism and implementing those mechanisms in system based approach will help us in the development of mixture model. This will provide better understanding of the risk produced by chemical mixture exposure and it will further assist in designing animal experiment and optimization of dose which will reduce the use of animals. European Union, (2011) suggested concentration addition method for cumulative risk assessment of chemicals with similar or dissimilar mechanism of action by considering their common adverse outcomes. But response addition method for a common adverse effect is still not recommended.

Categorization of chemicals in same group according to similar adverse outcomes, accounting both similar as well as dissimilar mechanism (crosstalk) of action may provide sound basis for studying mixture toxicology. Based on this grouping strategy, addressing both kinetic and dynamic interaction of mixture and establishing a relationship between pharmacokinetic - pharmacodynamic- altered molecular events will give a better model to correlate the environment exposure with adverse outcomes. Finally, integrating individual mode of action of each chemical by the help of mathematic equation into advanced tools such as PBPK/PD would enable the simultaneous assessment of EDCs mixtures correlating concentration in various biological matrixes (blood, tissue, urine) with various end points (endocrine diseases). It will also help in finding the toxic equivalent dose of chemical eliciting similar adverse 
effect. Similarly, timing and duration of exposure is another important factor which needs to be considered while assessing the risk. Integrating physiology of human body at different life stages and respective mode of action of EDCs will help in building life stage dynamic model. For example, dividing life stage into prenatal-postnatal-pubertymenopause and incorporating susceptible gene or receptor or protein at different life stage targeted by EDCs and physiological data provides a model able to predict the risk of infertility in females by exposure to these chemicals in different stage of life.

\section{Acknowledgements}

Preparation of this manuscript was supported in part for European Union's projects, HEALS (Health and Environment-wide Associations via Large population Surveys) by the FP7 Programme under grant agreement No 603946 and EuroMix (European Test and Risk Assessment Strategies for Mixtures) by the Horizon 2020 Framework Programme under gran agreement No. 633172. Raju Prasad Sharma has received doctoral fellowship from Universitat Rovira I Virgili under Martí-Franquès Research Grants Programme. This publication reflects only the authors' views. The Community and other funding organizations are not liable for any use made of the information contained therein.

\section{References}

Ackert, C.L., Gittens, J.E., O’Brien, M.J., Eppig, J.J., Kidder, G.M., 2001. Intercellular communication via connexin43 gap junctions is required for ovarian folliculogenesis in the mouse. Dev. Biol. 233, 258-270. doi:10.1006/dbio.2001.0216

Ahuja, H.S., Szanto, A., Nagy, L., Davies, P.J. A., 2003. The retinoid X receptor and its ligands: versatile regulators of metabolic function, cell differentiation and cell death. J. Biol. Regul. Homeost. Agents 17, 29-45.

Akingbemi, B.T., Sottas, C.M., Koulova, A.I., Klinefelter, G.R., Hardy, M.P., 2004. Inhibition of testicular steroidogenesis by the xenoestrogen bisphenol is associated with reduced pituitary luteinizing hormone secretion and decreased steroidogenic enzyme gene expression in rat leydig cells. Endocrinology 145, 592-603. doi:10.1210/en.20031174

Ansoumane, K., Duan, P., Quan, C., Yaima, M.L.T., Liu, C., Wang, C., Fu, W., Qi, S., Yu, T., Yang, K., 2014. Bisphenol A induced reactive oxygen species (ROS) in the liver and affect epididymal semen quality in adults Sprague-Dawley rats. J. Toxicol. Environ. Heal. Sci. 6, 103-112. doi:10.5897/JTEHS2014.0309

Anttonen, M., Parviainen, H., Kyrönlahti, A., Bielinska, M., Wilson, D.B., Ritvos, O., Heikinheimo, M., 2006. GATA-4 is a granulosa cell factor employed in inhibin- $\alpha$ activation by the TGF- $\beta$ pathway. J. Mol. Endocrinol. 36, 557-568. doi:10.1677/jme.1.01962

Atanasov, A.G., Tam, S., Röcken, J.M., Baker, M.E., Odermatt, A., 2003. Inhibition of $11 \beta$-hydroxysteroid dehydrogenase type 2 by dithiocarbamates. Biochem. Biophys. Res. Commun. 308, 257-262. doi:10.1016/S0006-291X(03)01359-7 
Bakker, J., De Mees, C., Douhard, Q., Balthazart, J., Gabant, P., Szpirer, J., Szpirer, C., 2006. Alpha-fetoprotein protects the developing female mouse brain from masculinization and defeminization by estrogens. Nat Neurosci 9, 220-226.

Baron, M., 2003. An overview of the Notch signalling pathway. Semin. Cell Dev. Biol. 14, 113-119. doi:10.1016/S1084-9521(02)00179-9

Beausoleil, C., Ormsby, J.N., Gies, A., Hass, U., Heindel, J.J., Holmer, M.L., Nielsen, P.J., Munn, S., Schoenfelder, G., 2013. Low dose effects and non-monotonic dose responses for endocrine active chemicals: Science to practice workshop: Workshop summary. Chemosphere 93, 847-856. doi:10.1016/j.chemosphere.2013.06.043

Billiar, R.B., Zachos, N.C., Burch, M.G., Albrecht, E.D., Pepe, G.J., 2003. Upregulation of alpha-inhibin expression in the fetal ovary of estrogen-suppressed baboons is associated with impaired fetal ovarian folliculogenesis. Biol. Reprod. 68, 1989-1996. doi:10.1095/biolreprod.102.011908

VanBirgelen, A.P., Smit, E.A., Kampen, I.M., 1995. Subchronic effects of 2, 3, 7, 8TCDD or PCBs on thyroid hormone metabolism: use in risk assessment. Eur. J. Pharmacol. Environ. Toxicol. 293, 77-85.

Boberg, J., Metzdorff, S., Wortziger, R., Axelstad, M., Brokken, L., Vinggaard, A.M., Dalgaard, M., Nellemann, C., 2008. Impact of diisobutyl phthalate and other PPAR agonists on steroidogenesis and plasma insulin and leptin levels in fetal rats. Toxicology 250, 75-81. doi:10.1016/j.tox.2008.05.020

Borum, K., 1961. Oogenesis in the mouse: A study of the meiotic prophase. Exp. Cell Res. 24, 495-507. doi:http://dx.doi.org/10.1016/0014-4827(61)90449-9

Bouskine, A., Nebout, M., Brücker-Davis, F., Banahmed, M., Fenichel, P., 2009. Low doses of bisphenol A promote human seminoma cell proliferation by activating PKA and PKG via a membrane G-protein-coupled estrogen receptor. Environ. Health Perspect. 117, 1053-1058. doi:10.1289/ehp.0800367

Brevini, T.A., Cillo, F., Antonini, S., Gandolfi, F., 2005. Effects of endocrine disrupters on the oocytes and embryos of farm animals. Reprod. Domest. Anim. 40, 291-299.

Buck Louis, G.M., Gray, L.E., Marcus, M., Ojeda, S.R., Pescovitz, O.H., Witchel, S.F., Sippell, W., Abbott, D.H., Soto, A., Tyl, R.W., Bourguignon, J.P., Skakkebaek, N.E., Swan, S.H., Golub, M.S., Wabitsch, M., Toppari, J., Euling, S.Y., 2008. Environmental Factors and Puberty Timing: Expert Panel Research Needs. Pediatrics 121, S192-S207. doi:10.1542/peds.1813E

Caldwell, J.C., Evans, M.V., Krishnan, K., 2012. Cutting edge PBPK models and analyses: Providing the basis for future modeling efforts and bridges to emerging toxicology paradigms. J. Toxicol. 2012. doi:10.1155/2012/852384

Casals-Casas, C., Desvergne, B., 2011. Endocrine disruptors: from endocrine to metabolic disruption. Annu. Rev. Physiol. 73, 135-162. doi:10.1146/annurev-physiol012110-142200

Caserta, D., Maranghi, L., Mantovani, A., Marci, R., Maranghi, F., Moscarini, M., 2008. Impact of endocrine disruptor chemicals in gynaecology. Hum. Reprod. Update 14, 59-72. doi:10.1093/humupd/dmm025

Castrillon, D.H., Miao, L., Kollipara, R., Horner, J.W., DePinho, R.A., 2003. 
Suppression of ovarian follicle activation in mice by the transcription factor Foxo3a. Science 301, 215-218. doi:10.1126/science.1086336

Castro, B., Sánchez, P., Torres, J.M., Preda, O., del Moral, R.G., Ortega, E., 2013. Bisphenol a exposure during adulthood alters expression of aromatase and $5 \alpha$-reductase isozymes in rat prostate. PLoS One 8, 1-7. doi:10.1371/journal.pone.0055905

Ceccarelli, I., Della Seta, D., Fiorenzani, P., Farabollini, F., Aloisi, A.M., 2007. Estrogenic chemicals at puberty change ER $\alpha$ in the hypothalamus of male and female rats. Neurotoxicol. Teratol. 29, 108-115. doi:http://dx.doi.org/10.1016/j.ntt.2006.10.011

Chandrashekar, V., Bartke, A., 1993. Induction of endogenous insulin-like growth factor-I secretion alters the hypothalamic-pituitary-testicular function in growth hormone-deficient adult dwarf mice. Biol. Reprod. 48, 544-551. doi:10.1095/biolreprod48.3.544

Chang, H.M., Cheng, J.C., Leung, P.C.K., 2013. Theca-derived BMP4 and BMP7 down-regulate connexin43 expression and decrease gap junction intercellular communication activity in immortalized human granulosa cells. J. Clin. Endocrinol. Metab. 98, 437-445. doi:10.1210/jc.2012-3851

Chang, H.M., Cheng, J.C., Taylor, E., Leung, P.C.K., 2014. Oocyte-derived BMP15 but not GDF9 down-regulates connexin43 expression and decreases gap junction intercellular communication activity inimmortalized human granulosa cells. Mol. Hum. Reprod. 20, 373-383. doi:10.1093/molehr/gau001

Chang, Z., Lu, M., Kim, S.S., Park, J.S., 2014. Potential role of HSP90 in mediating the interactions between estrogen receptor (ER) and aryl hydrocarbon receptor (AhR) signaling pathways. Toxicol. Lett. 226, 6-13. doi:10.1016/j.toxlet.2014.01.032

Chao, H.H., Zhang, X.F., Chen, B., Pan, B., Zhang, L.J., Li, L., Sun, X.F., Shi, Q.H., Shen, W., 2012. Bisphenol A exposure modifies methylation of imprinted genes in mouse oocytes via the estrogen receptor signaling pathway. Histochem. Cell Biol. 137, 249-259. doi:10.1007/s00418-011-0894-z

Chen, C.L., Fu, X.F., Wang, L.Q., Wang, J.J., Ma, H.G., Cheng, S.F., Hou, Z.M., Ma, J.M., Quan, G.B., Shen, W., Li, L., 2014. Primordial follicle assembly was regulated by notch signaling pathway in the mice. Mol. Biol. Rep. 41, 1891-1899. doi:10.1007/s11033-014-3038-4

Chen, Y., Breen, K., Pepling, M.E., 2009. Estrogen can signal through multiple pathways to regulate oocyte cyst breakdown and primordial follicle assembly in the neonatal mouse ovary. J. Endocrinol. 202, 407-417. doi:10.1677/JOE-09-0109

Chen, Y., Jefferson, W.N., Newbold, R.R., Padilla-Banks, E., Pepling, M.E., 2007. Estradiol, progesterone, and genistein inhibit oocyte nest breakdown and primordial follicle assembly in the neonatal mouse ovary in vitro and in vivo. Endocrinology 148, 3580-3590. doi:10.1210/en.2007-0088

Cheng, C.Y., Wong, E.W., Lie, P.P., Li, M.W., Su, L., Siu, E.R., Yan, H.H., Mannu, J., Mathur, P.P., Bonanomi, M., Silvestrini, B., Mruk, D.D., 2011. Environmental toxicants and male reproductive function 1, 2-13. doi:10.4161/spmg.1.1.13971

Chitra, K.C., Latchoumycandane, C., Mathur, P.P., 2003. Induction of oxidative stress by bisphenol $\mathrm{A}$ in the epididymal sperm of rats. Toxicology 185, 119-127. 
Chu, D.P., Tian, S., Qi, L., Hao, C.J., Xia, H.F., Ma, X., 2013. Abnormality of maternal-to-embryonic transition contributes to MEHP-induced mouse 2-cell block. J. Cell. Physiol. 228, 753-763. doi:10.1002/jcp.24222

Clarkson, W., 1995. Environmental contamination in food chain. Am. J. Clin. nutrtion $61,682 \mathrm{~S}-6 \mathrm{~S}$.

Clewell, R. A., Merrill, E. A., Narayanan, L., Gearhart, J.M., Robinson, P.J., 2004. Evidence for competitive inhibition of iodide uptake by perchlorate and translocation of perchlorate into the thyroid. Int. J. Toxicol. 23, 17-23. doi: $10.1080 / 10915810490275044$

Cooper, R.L., Stoker, T.E., Tyrey, L., Goldman, J.M., McElroy, W.K., 2000. Atrazine disrupts the hypothalamic control of pituitary-ovarian function. Toxicol. Sci. 53, 297307. doi:10.1093/toxsci/53.2.297

Craig, Z.R., Wang, W., Flaws, J. A., 2011. Endocrine-disrupting chemicals in ovarian function: effects on steroidogenesis, metabolism and nuclear receptor signaling. Reproduction 142, 633-646. doi:10.1530/REP-11-0136

Crisp, T.M., Clegg, E.D., Cooper, R.L., Wood, W.P., Anderson, D.G., Baetcke, K.P., Hoffmann, J.L., Morrow, M.S., Rodier, D.J., Schaeffer, J.E., Touart, L.W., Zeeman, M.G., Patel, Y.M., 1998. Environmental endocrine disruption: an effects assessment and analysis. Environ. Health Perspect. 106 Suppl , 11-56. doi:10.1289/ehp.98106s 111

Cruz, G., Foster, W., Paredes, A., Yi, K.D., Uzumcu, M., 2014. Long-term effects of early-life exposure to environmental oestrogens on ovarian function: Role of epigenetics. J. Neuroendocrinol. 26, 613-624. doi:10.1111/jne.12181

Culleres, D.B., Boesten, J., Bolognesi, C., Boobis, A., Büchert, A., Coggon, D., Hardy, A., Hart, A., Köpp, H., Liess, M., Luttik, R., Meyer, O., Michaelidou-canna, S., Montforts, M., Moretto, A., Müller, M., Ossendorp, B., Steurbaut, W., Tasheva, M., Vleminckx, C., 2008. Opinion of the Scientific Panel on Plant Protection products and their Residues to evaluate the suitability of existing methodologies. EFSA J. 704, 1-84.

Doering, D.D., Steckelbroeck, S., Doering, T., Klingmüller, D., 2002. Effects of butyltins on human 5alpha-reductase type 1 and type 2 activity. Steroids 67, 859-867.

Durlinger, A.L.L., Kramer, P., Karels, B., De Jong, F.H., Uilenbroek, J.T.J., Anton Grootegoed, J., Themmen, A.P.N., 1999. Control of primordial follicle recruitment by anti-mullerian hormone in the mouse ovary. Endocrinology 140, 5789-5796. doi:10.1210/en.140.12.5789

EFSA, 2013. Scientific Opinion on the relevance of dissimilar mode of action and its appropriate application for cumulative risk assessment of pesticides 11 . doi:10.2903/j.efsa.2013.3472

EU, 2011. Scientific Committee on Health and Environmental Risks SCHER Scientific Committee on Emerging and Newly Identified Health Risks SCENIHR Scientific Committee on Consumer Safety SCCS Toxicity and Assessment of Chemical Mixtures. Eur. commision Toxic. Assess. Chem. Mix. 1-50. doi:10.2772/37863

EU, 2010. Directive 2010/63/EU of the European parliament and of the council of 22 September 2010 on the protection of animals used for scientific purposes. Off. J. Eur. 
Union 276, 33-74.

Euling, S.Y., Selevan, S.G., Pescovitz, O.H., Skakkebaek, N.E., 2008. Role of Environmental Factors in the Timing of Puberty. Pediatrics 121, S167-S171. doi:10.1542/peds.2007-1813C

Fan, J., Papadopoulos, V., 2012. Transcriptional Regulation of Translocator Protein (Tspo) via a SINE B2-Mediated Natural Antisense Transcript in MA-10 Leydig Cells. Biol. Reprod. 86, 147-147. doi:10.1095/biolreprod.111.097535

Fang, H., Tong, W., Branham, W.S., Moland, C.L., Dial, S.L., Hong, H., Xie, Q., Perkins, R., Owens, W., Sheehan, D.M., 2003. Study of 202 Natural, Synthetic, and Environmental Chemicals for Binding to the Androgen Receptor. Chem. Res. Toxicol. 16, 1338-1358. doi:10.1021/tx030011g

Fenton, S.E., 2006. Endocrine-disrupting compounds and mammary gland development: Early exposure and later life consequences. Endocrinology 147, 18-24. doi:10.1210/en.2005-1131

Filby, A.L., Neuparth, T., Thorpe, K.L., Owen, R., Galloway, T.S., Tyler, C.R., 2007. Health impacts of estrogens in the environment, considering complex mixture effects. Environ. Health Perspect. 115, 1704-1710. doi:10.1289/ehp.10443

Flamant, F., Gauthier, K., Samarut, J., 2007. Thyroid hormones signaling is getting more complex: STORMs are coming. Mol. Endocrinol. 21, 321-333. doi:10.1210/me.2006-0035

Fowler, P. A., Bellingham, M., Sinclair, K.D., Evans, N.P., Pocar, P., Fischer, B., Schaedlich, K., Schmidt, J.S., Amezaga, M.R., Bhattacharya, S., Rhind, S.M., O'Shaughnessy, P.J., 2012. Impact of endocrine-disrupting compounds (EDCs) on female reproductive health. Mol. Cell. Endocrinol. 355, 231-239. doi:10.1016/j.mce.2011.10.021

Fraser, H.M., Dickson, S.E., Lunn, S.F., Wulff, C., Morris, K.D., Carroll, V. A., Bicknell, R., 2000. Suppression of luteal angiogenesis in the primate after neutralization of vascular endothelial growth factor. Endocrinology 141, 995-1000. doi:10.1210/en.141.3.995

Friedmann, A.S., 2002. Atrazine inhibition of testosterone production in rat males following peripubertal exposure. Reprod. Toxicol. 16, 275-279. doi:10.1016/S08906238(02)00019-9

Fukuzawa, N.H., Ohsako, S., Wu, Q., Sakaue, M., Fujii-Kuriyama, Y., Baba, T., Tohyama, C., 2004. Testicular cytochrome P450scc and LHR as possible targets of 2,3,7,8-tetrachlorodibenzo-p-dioxin (TCDD) in the mouse. Mol. Cell. Endocrinol. 221, 87-96. doi:10.1016/j.mce.2004.02.005

Gandolfi, F., Pocar, P., Brevini, T.A.L., Fischer, B., 2002. Impact of endocrine disrupters on ovarian function and embryonic development. Domest. Anim. Endocrinol. 23, 189-201. doi:10.1016/S0739-7240(02)00156-X

Garcia-reyero, N., Martyniuk, C.J., Kroll, K.J., Escalon, B.L., Spade, D.J., Denslow, N.D., 2015. HHS Public Access 159-169.

doi:10.1016/j.ygcen.2013.06.008.Transcriptional

Giammona, C., 2002. Death Receptor Response in Rodent Testis after Mono-(2- 
ethylhexyl) Phthalate Exposure. Toxicol. Appl. Pharmacol. 185, 119-127. doi:10.1006/taap.2002.9536

Gittens, J.E.I., Barr, K.J., Vanderhyden, B.C., Kidder, G.M., 2005. Interplay between paracrine signaling and gap junctional communication in ovarian follicles. J. Cell Sci. 118, 113-122. doi:10.1242/jcs.01587

Gore, A.C., Crews, D., Doan, L.L., La Merrill, M., Patisaul, H., Zota, A., 2014. Introduction to endocrine disrupting chemicals (EDCs): A guide for public interest organizations and policy-makers.

Grün, F., Blumberg, B., 2006. Environmental obesogens: Organotins and endocrine disruption via nuclear receptor signaling. Endocrinology 147, 50-55. doi:10.1210/en.2005-1129

Gumy, C., Chandsawangbhuwana, C., Dzyakanchuk, A. A., Kratschmar, D. V., Baker, M.E., Odermatt, A., 2008. Dibutyltin disrupts glucocorticoid receptor function and impairs glucocorticoid-induced suppression of cytokine production. PLoS One 3. doi:10.1371/journal.pone.0003545

Haimes, Y.Y., 2009. On the Complex Definition of Risk: A Systems-Based Approach. Risk Anal. 29, 1647-1654. doi:10.1111/j.1539-6924.2009.01310.x

Hameed, S., Jayasena, C.N., Dhillo, W.S., 2011. Kisspeptin and fertility. J. Endocrinol. 208, 97-105. doi:10.1677/JOE-10-0265

Hampl, R., Kubátová, J., Stárka, L., 2014. Steroids and endocrine disruptors-History, recent state of art and open questions. J. Steroid Biochem. Mol. Biol. doi:10.1016/j.jsbmb.2014.04.013

Hankinson, O., 1994. The role of the aryl hydrocarbon receptor nuclear translocator protein in aryl hydrocarbon receptor action. Trends Endocrinol. Metab. 5, 240-244. doi:10.1016/1043-2760(94)P3082-I

Hannon, P.R., Peretz, J., Flaws, J.A., 2014. Daily Exposure to Di(2-ethylhexyl) Phthalate Alters Estrous Cyclicity and Accelerates Primordial Follicle Recruitment Potentially Via Dysregulation of the Phosphatidylinositol 3-Kinase Signaling Pathway in Adult Mice. Biol. Reprod. 90, 136. doi:10.1095/biolreprod.114.119032

Hany, J., Lilienthal, H., Sarasin, A., Roth-Härer, A., Fastabend, A., Dunemann, L., Lichtensteiger, W., Winneke, G., 1999. Developmental exposure of rats to a reconstituted PCB mixture or aroclor 1254: effects on organ weights, aromatase activity, sex hormone levels, and sweet preference behavior. Toxicol. Appl. Pharmacol. 158, 231-243. doi:10.1006/taap.1999.8710

Hauet, T., Yao, Z.X., Bose, H.S., Wall, C.T., Han, Z., Li, W., Hales, D.B., Miller, W.L., Culty, M., Papadopoulos, V., 2005. Peripheral-type benzodiazepine receptor-mediated action of steroidogenic acute regulatory protein on cholesterol entry into Leydig cell mitochondria. Mol. Endocrinol. 19, 540-554. doi:10.1210/me.2004-0307

Hayes, T.B., Anderson, L.L., Beasley, V.R., de Solla, S.R., Iguchi, T., Ingraham, H., Kestemont, P., Kniewald, J., Kniewald, Z., Langlois, V.S., Luque, E.H., McCoy, K.A., Muñoz-de-Toro, M., Oka, T., Oliveira, C.A., Orton, F., Ruby, S., Suzawa, M., TaveraMendoza, L.E., Trudeau, V.L., Victor-Costa, A.B., Willingham, E., 2011. Demasculinization and feminization of male gonads by atrazine: Consistent effects 
across vertebrate classes. J. Steroid Biochem. Mol. Biol. 127, 64-73. doi:10.1016/j.jsbmb.2011.03.015

Heidrich, D.D., Steckelbroeck, S., Klingmuller, D., 2001. Inhibition of human cytochrome P450 aromatase activity by butyltins. Steroids $66,763-769$.

Hillier, S.G., Reichert L.E., Van hall, E. V., 1981. Control of preovulatory follicular estrogen biosynthesis in the human ovary. J. Clin. Endocrinol. Metab. 52, 847-856.

Hirshfield, A. N., Midgley, A. R., 1978. The role of FSH in the selection of large ovarian follicles in the rat. Biol. Reprod. 19, 606-611. doi:10.1095/biolreprod19.3.606

Hull, K.L., Harvey, S., 2000. Growth hormone: Roles in male reproduction. Endocrine 13, 243-250. doi:10.1385/ENDO:13:3:243

Ikeda, Y., Nagai, A., Ikeda, M.A., Hayashi, S., 2002. Increased expression of Mullerian-inhibiting substance correlates with inhibition of follicular growth in the developing ovary of rats treated with E2 benzoate. Endocrinology 143, 304-312. doi:10.1210/en.143.1.304

Iwamuro, S., Yamada, M., Kato, M., Kikuyama, S., 2006. Effects of bisphenol A on thyroid hormone-dependent up-regulation of thyroid hormone receptor $\alpha$ and $\beta$ and down-regulation of retinoid X receptor $\gamma$ in Xenopus tail culture. Life Sci. 79, 21652171. doi:10.1016/j.lfs.2006.07.013

Johansson, M., Larsson, C., Bergman, A., Lund, B.O., 1998. Structure-activity relationship for inhibition of CYP11B1-dependent glucocorticoid synthesis in Y1 cells by aryl methyl sulfones. Pharmacol. Toxicol. 83, 225-230.

Jones, R.L., Pepling, M.E., 2013. KIT signaling regulates primordial follicle formation in the neonatal mouse ovary. Dev. Biol. 382, 186-197. doi:10.1016/j.ydbio.2013.06.030

Juge-Aubry, C.E., Gorla-Bajszczak, A., Pernin, A., Lemberger, T., Wahli, W., Burger, A.G., Meier, C. A., 1995. Peroxisome proliferator-activated receptor mediates cross-talk with thyroid hormone receptor by competition for retinoid $\mathrm{X}$ receptor: Possible role of a leucine zipper-like heptad repeat. J. Biol. Chem. doi:10.1074/jbc.270.30.18117

Kaczmarek, M.M., Schams, D., Ziecik, A.J., 2005. Role of vascular endothelial growth factor in ovarian physiology - an overview. Reprod. Biol. 5, 111-136.

Karri, V., Schuhmacher, M., Kumar, V., 2016. Heavy metals (Pb, Cd, MeHg, As) as risk factors for cognitive dysfunction: A general review of metal mixture mechanism in Brain, Environmental Toxicology and Pharmacology (Accepted).

Kazlauskas, A., Poellinger, L., Pongratz, I., 1999. Evidence that the co-chaperone p23 regulates ligand responsiveness of the dioxin (aryl hydrocarbon) receptor. J. Biol. Chem. 274, 13519-13524. doi:10.1074/jbc.274.19.13519

Kee, K., Flores, M., Cedars, M.I., Pera, R.A.R., 2010. Human primordial germ cell formation is diminished by exposure to environmental toxicants acting through the ahr signaling pathway. Toxicol. Sci. 117, 218-224. doi:10.1093/toxsci/kfq179

Kester, M.H.A., Bulduk, S., Van Toor, H., Tibboel, D., Meinl, W., Glatt, H., Falany, C.N., Coughtrie, M.W.H., Gerlienke Schuur, A., Brouwer, A., Visser, T.J., 2002. Potent inhibition of estrogen sulfotransferase by hydroxylated metabolites of polyhalogenated aromatic hydrocarbons reveals alternative mechanism for estrogenic activity of 
endocrine disrupters. J. Clin. Endocrinol. Metab. 87, 1142-1150. doi:10.1210/jc.87.3.1142

Kitawaki, J., Kado, N., Ishihara, H., Koshiba, H., Kitaoka, Y., Honjo, H., 2002. Endometriosis: the pathophysiology as an estrogen-dependent disease. J. Steroid Biochem. Mol. Biol. 83, 149-155. doi:10.1016/S0960-0760(02)00260-1

Knudsen, T.B., Keller, D.A., Sander, M., Carney, E.W., Doerrer, N.G., Eaton, D.L., Fitzpatrick, S.C., Hastings, K.L., Mendrick, D.L., Tice, R.R., Watkins, P.B., Whelan, M., 2015. FutureTox II: In vitro data and in silico models for predictive toxicology. Toxicol. Sci. 143, 256-267. doi:10.1093/toxsci/kfu234

Koji, T., Hishikawa, Y., Ando, H., Nakanishi, Y., Kobayashi, N., 2001. Expression of Fas and Fas ligand in normal and ischemia-reperfusion testes: involvement of the Fas system in the induction of germ cell apoptosis in the damaged mouse testis. Biol. Reprod. 64, 946-954. doi:10.1095/biolreprod64.3.946

Kortenkamp, A., 2007. Ten Years of Mixing Cocktails: A Review of Combination Effects of Endocrine-Disrupting Chemicals. Environ. Health Perspect. 115, 98-105. doi:10.1289/ehp.9357

Krozowski, Z., Li, K.X., Koyama, K., Smith, R., Obeyesekere, V., Stein-Oakley, A., Sasano, H., Coulter, C., Cole, T., Sheppard, K., 1999. The type I and type II 11 $\beta$ hydroxysteroid dehydrogenase enzymes. J. Steroid Biochem. Mol. Biol. 69, 391-401. doi:10.1016/S0960-0760(99)00074-6

Krozowski, Z., MaGuire, J.A., Stein-Oakley, A.N., Dowling, J., Smith, R.E., Andrews, R.K., 1995. Immunohistochemical localization of the 11 beta-hydroxysteroid dehydrogenase type II enzyme in human kidney and placenta. J. Clin. Endocrinol. Metab. 80, 2203-2209. doi:10.1210/jcem.80.7.7608280

Kupelian, V., Page, S.T., Araujo, A.B., Travison, T.G., Bremner, W.J., McKinlay, J.B., 2006. Low Sex Hormone-Binding Globulin, Total Testosterone, and Symptomatic Androgen Deficiency Are Associated with Development of the Metabolic Syndrome in Nonobese Men. J. Clin. Endocrinol. Metab. 91, 843-850. doi:10.1210/jc.2005-1326

Kwintkiewicz, J., Nishi, Y., Yanase, T., Giudice, L.C., 2010. Peroxisome proliferatoractivated receptor- $\gamma$ mediates bisphenol A inhibition of FSH-stimulated IGF-1, aromatase, and estradiol in human granulosa cells. Environ. Health Perspect. 118, 400406. doi:10.1289/ehp.0901161

La Sala, G., Farini, D., De Felici, M., 2009. Proapoptotic effects of lindane on mouse primordial germ cells. Toxicol. Sci. 108, 445-451. doi:10.1093/toxsci/kfp027

Lackey, B.R., Gray, S.L., Henricks, D.M., 2001. Crosstalk and considerations in endocrine disruptor research. Med Hypotheses 56, 644-7. doi:10.1054/mehy.2000.1249

Lai, K.P., Wong, M.H., Wong, C.K.C., 2005a. Inhibition of CYP450scc expression in dioxin-exposed rat Leydig cells. J. Endocrinol. 185, 519-527. doi:10.1677/joe.1.06054

Lai, K.P., Wong, M.H., Wong, C.K.C., 2005b. Effects of TCDD in modulating the expression of Sertoli cell secretory products and markers for cell-cell interaction. Toxicology 206, 111-123. doi:10.1016/j.tox.2004.07.002

Lambert, J.C., Lipscomb, J.C., 2007. Mode of action as a determining factor in additivity models for chemical mixture risk assessment. Regul. Toxicol. Pharmacol. 49, 
Lans, M.C., Spiertz, C., Brouwer, A., Koeman, J.H., 1994. Different competition of thyroxine binding to transthyretin and thyroxine-binding globulin by hydroxy-PCBs, PCDDs and PCDFs. Eur. J. Pharmacol. 270, 129-136. doi:10.1016/09266917(94)90054-X

Lee, J., Richburg, J.H., Shipp, E.B., Meistrich, M.L., Boekelheide, K., 1999. The Fas system, a regulator of testicular germ cell apoptosis, is differentially up-regulated in Sertoli cell versus germ cell injury of the testis. Endocrinology 140, 852-858. doi:10.1210/en.140.2.852

Lee, M.M., Donahoe, P.K., 1993. Mullerian Inhibiting Substance: A Gonadal Hormone with Multiple Functions. Endocr. Rev. 14, 152-164. doi:10.1210/edrv-14-2-152

Lee, V.W.K., Mcmaster, J., Quigg, H., Leversha, L., 1982. Ovarian and Circulating Inhibin Levels in Immature Female Rats Treated with Gonadotropin and after Castration. Endocrinology 111, 1849-1854.

Lee, W., Yoon, S., Yoon, T., Cha, K., Lee, S., Shimasaki, S., Lee, S., Lee, K., 2004. Effects of bone morphogenetic protein-7 (BMP-7) on primordial follicular growth in the mouse ovary. Mol. Reprod. Dev. 69, 159-163.

Lemaire, G., Terouanne, B., Mauvais, P., Michel, S., Rahmani, R., 2004. Effect of organochlorine pesticides on human androgen receptor activation in vitro. Toxicol. Appl. Pharmacol. 196, 235-246. doi:10.1016/j.taap.2003.12.011

Li, L. A., Wang, P.W., Chang, L.W., 2004. Polychlorinated biphenyl 126 stimulates basal and inducible aldosterone biosynthesis of human adrenocortical H295R cells. Toxicol. Appl. Pharmacol. 195, 92-102. doi:10.1016/j.taap.2003.11.007

Li, M.W.M., Mruk, D.D., Lee, W.M., Cheng, C.Y., 2009. Disruption of the blood-testis barrier integrity by bisphenol A in vitro: Is this a suitable model for studying bloodtestis barrier dynamics? Int. J. Biochem. Cell Biol. 41, 2302-2314. doi:10.1016/j.biocel.2009.05.016

Li, Y., Ramdhan, D.H., Naito, H., Yamagishi, N., Ito, Y., Hayashi, Y., Yanagiba, Y., Okamura, A., Tamada, H., Gonzalez, F.J., Nakajima, T., 2011. Ammonium perfluorooctanoate may cause testosterone reduction by adversely affecting testis in relation to PPAR $\alpha$. Toxicol. Lett. 205, 265-272. doi:10.1016/j.toxlet.2011.06.015

Luque, R.M., Kineman, R.D., Tena-Sempere, M., 2007. Regulation of hypothalamic expression of KiSS-1 and GPR54 genes by metabolic factors: Analyses using mouse models and a cell line. Endocrinology 148, 4601-4611. doi:10.1210/en.2007-0500

Maffini, M. V., Rubin, B.S., Sonnenschein, C., Soto, A.M., 2006. Endocrine disruptors and reproductive health: The case of bisphenol-A. Mol. Cell. Endocrinol. 254-255, 179186. doi:10.1016/j.mce.2006.04.033

Manna, P.R., Roy, P., Clark, B.J., Stocco, D.M., Huhtaniemi, I.T., 2001. Interaction of thyroid hormone and steroidogenic acute regulatory (StAR) protein in the regulation of murine Leydig cell steroidogenesis. J. Steroid Biochem. Mol. Biol. 76, 167-177. doi:10.1016/S0960-0760(00)00156-4

Manna, P.R., Stocco, D.M., 2005. Regulation of the steroidogenic acute regulatory protein expression: functional and physiological consequences. Curr. Drug Targets- 
Immune, Endocr. Metab. Disord. 5, 93-108.

Marrapodi, M., Chiang, J.Y.L., 2000. Peroxisome proliferator-activated receptor $\alpha$ (PPAR $\alpha$ ) and agonist inhibit cholesterol $7 \alpha$-hydroxylase gene (CYP7A1) transcription. J. Lipid Res. 41, 514-520.

Masuyama, H., Hiramatsu, Y., Kunitomi, M., Kudo, T., MacDonald, P.N., 2000. Endocrine disrupting chemicals, phthalic acid and nonylphenol, activate Pregnane $\mathrm{X}$ receptor-mediated transcription. Mol. Endocrinol. 14, 421-428. doi:10.1210/mend.14.3.0424

Masuyama, H., Inoshita, H., Hiramatsu, Y., Kudo, T., 2002. Ligands have various potential effects on the degradation of pregnane $\mathrm{X}$ receptor by proteasome. Endocrinology 143, 55-61. doi:10.1210/en.143.1.55

Matikainen, T.M., Moriyama, T., Morita, Y., Perez, G.I., Korsmeyer, S.J., Sherr, D.H., Tilly, J.L., 2002. Ligand activation of the aromatic hydrocarbon receptor transcription factor drives Bax-dependent apoptosis in developing fetal ovarian germ cells. Endocrinology 143, 615-620. doi:10.1210/en.143.2.615

Matthiessen, P., Johnson, I., 2007. Implications of research on endocrine disruption for the environmental risk assessment, regulation and monitoring of chemicals in the European Union. Environ. Pollut. 146, 9-18. doi:10.1016/j.envpol.2006.05.036

Meeker, J.D., Godfrey-Bailey, L., Hauser, R., 2006. Relationships Between Serum Hormone Levels and Semen Quality Among Men From an Infertility Clinic. J. Androl. 28, 397-406. doi:10.2164/jandrol.106.001545

Mikamo, E., Harada, S., Nishikawa, J., Nishihara, T., 2003. Endocrine disruptors induce cytochrome $\mathrm{P} 450$ by affecting transcriptional regulation via pregnane $\mathrm{X}$ receptor. Toxicol. Appl. Pharmacol. 193, 66-72. doi:10.1016/j.taap.2003.08.001

Miller, W.L., 1988. Molecular Biology of Steroid Hormone Synthesis. Endocr. Rev. 9, 295-318. doi:10.1210/edrv-9-3-295

Mimura, J., Ema, M., Sogawa, K., Fujii-Kuriyama, Y., 1999. Identification of a novel mechanism of regulation of Ahr (dioxin) receptor function. Genes Dev. 13, 20-25. doi:10.1101/gad.13.1.20

Moriyama, K., Tagami, T., Akamizu, T., Usui, T., Saijo, M., Kanamoto, N., Hataya, Y., Shimatsu, A., Kuzuya, H., Nakao, K., 2002. Thyroid hormone action is disrupted by bisphenol $A$ as an antagonist. J. Clin. Endocrinol. Metab. 87, 5185-5190. doi:10.1210/jc.2002-020209

Muczynski, V., Lecureuil, C., Messiaen, S., Guerquin, M.J., N'Tumba-Byn, T., Moison, D., Hodroj, W., Benjelloun, H., Baijer, J., Livera, G., Frydman, R., Benachi, A., Habert, R., Rouiller-Fabre, V., 2012. Cellular and Molecular Effect of MEHP Involving LXR $\alpha$ in Human Fetal Testis and Ovary. PLoS One 7. doi:10.1371/journal.pone.0048266

N'Diaye, M.R., Sun, S.S., Fanua, S.P., Loseth, K.J., Shaw Wilgis, E.F., Crabo, B.G., 2002. Growth hormone receptors in the porcine testis during prepuberty. Reprod. Domest. Anim. 37, 305-309. doi:10.1046/j.1439-0531.2002.00364.x

Nagel, S.C., Frederick, S., Welshons, W. V, 1999. Developmental estrogenic chemicals are predicted by an in vitro assay incorporating modification of cell uptake by serum. J. Steroid Biochem. Mol. Biol. 69, 343-357. 
Nanjappa, M.K., Simon, L., Akingbemi, B.T., 2012. The Industrial Chemical Bisphenol A (BPA) Interferes with Proliferative Activity and Development of Steroidogenic Capacity in Rat Leydig Cells. Biol. Reprod. 86, 135-135. doi:10.1095/biolreprod.111.095349

Nestorov, I., 2007. Whole-body physiologically based pharmacokinetic models. Expert Opin. Drug Metab. Toxicol. 3, 235-249. doi:10.1517/17425255.3.2.235

Neurons, G.H., Magni, P., Vettor, R., Pagano, C., Calcagno, A., Beretta, E., Messi, E., Zanisi, M., Martini, L., Motta, M., 1999. Expression of a Leptin Receptor in Immortalized 140, 1581-1585.

Nikula, H., Talonpoika, T., Kaleva, M., Toppari, J., 1999. Inhibition of hCG-stimulated steroidogenesis in cultured mouse Leydig tumor cells by bisphenol A and octylphenols. Toxicol. Appl. Pharmacol. 157, 166-173. doi:10.1006/taap.1999.8674

Nilsson, E.E., Skinner, M.K., 2003. Bone morphogenetic protein-4 acts as an ovarian follicle survival factor and promotes primordial follicle development. Biol. Reprod. 69, 1265-1272. doi:10.1095/biolreprod.103.018671

Nilsson, E.E., Skinner, M.K., 2002. Growth and differentiation factor-9 stimulates progression of early primary but not primordial rat ovarian follicle development. Biol. Reprod. 67, 1018-1024. doi:10.1095/biolreprod.101.002527

Niwa, T., Fujimoto, M., Kishimoto, K., Yabusaki, Y., Ishibashi, F., Katagiri, M., 2001. Metabolism and interaction of bisphenol A in human hepatic cytochrome P450 and steroidogenic CYP17. Biol. Pharm. Bull. 24, 1064-1067. doi:10.1248/bpb.24.1064

Ohshima, M., Ohno, S., Nakajin, S., 2005. Inhibitory effects of some possible endocrine-disrupting chemicals on the isozymes of human 11beta-hydroxysteroid dehydrogenase and expression of their mRNA in gonads and adrenal glands. Environ. Sci. 12, 219-230.

Ohtake, F., Baba, A., Takada, I., Okada, M., Iwasaki, K., Miki, H., Takahashi, S., Kouzmenko, A., Nohara, K., Chiba, T., Fujii-Kuriyama, Y., Kato, S., 2007. Dioxin receptor is a ligand-dependent E3 ubiquitin ligase. Nature 446, 562-566. doi: $10.1038 /$ nature 05683

Ohtake, F., Takeyama, K., Matsumoto, T., Kitagawa, H., Yamamoto, Y., Nohara, K., Tohyama, C., Krust, A., Mimura, J., Chambon, P., Yanagisawa, J., Fujii-Kuriyama, Y., Kato, S., 2003. Modulation of oestrogen receptor signalling by association with the activated dioxin receptor. Nature 423, 545-550. doi:10.1038/nature01606

Palanza, P., Nagel, S.C., Parmigiani, S., vom Saal, F.S., 2016. Perinatal exposure to endocrine disruptors: Sex, timing and behavioral endpoints. Curr. Opin. Behav. Sci. 7, 69-75. doi:10.1016/j.cobeha.2015.11.017

Parker, K.L., Schimmer, B.P., 1995. Transcriptional regulation of the genes encoding the cytochrome P-450 steroid hydroxylases. Vitam. Horm. 51, 339-370.

Parrott, J.A., Skinner, M.K., 1999. Kit-Ligand/Stem Cell Factor Induces Primordial Follicle Development and Initiates Folliculogenesis. Endocrinology 140, 4262-4271. doi:10.1210/endo.140.9.6994

Patisaul, H.B., Todd, K.L., Mickens, J. A., Adewale, H.B., 2009. Impact of neonatal exposure to the ER $\alpha$ agonist PPT, bisphenol-A or phytoestrogens on hypothalamic 
kisspeptin fiber density in male and female rats. Neurotoxicology 30, 350-357. doi:10.1016/j.neuro.2009.02.010

Pepling, M.E., Spradling, A. C., 2001. Mouse ovarian germ cell cysts undergo programmed breakdown to form primordial follicles. Dev. Biol. 234, 339-351. doi:10.1006/dbio.2001.0269

Pepling, M.E., Spradling, A. C., 1998. Female mouse germ cells form synchronously dividing cysts. Development 125, 3323-3328.

Perdew, G.H., 1988. Association of the Ah receptor with the 90-kDa heat shock protein. J. Biol. Chem. 263, 13802-13805. doi:10.1073/pnas.1302856110

Peretz, J., Gupta, R.K., Singh, J., Hernández-Ochoa, I., Flaws, J. A., 2011. Bisphenol A impairs follicle growth, inhibits steroidogenesis, and downregulates rate-limiting enzymes in the estradiol biosynthesis pathway. Toxicol. Sci. 119, 209-217. doi:10.1093/toxsci/kfq319

Perillo, B., Sasso, A., Abbondanza, C., Palumbo, G., 2000. 17beta-estradiol inhibits apoptosis in MCF-7 cells, inducing bcl-2 expression via two estrogen-responsive elements present in the coding sequence. Mol. Cell. Biol. 20, 2890-2901. doi:10.1128/MCB.20.8.2890-2901.2000

Petro, E.M.L., Leroy, J.L.M.R., Covaci, A., Fransen, E., De Neubourg, D., Dirtu, A.C., De Pauw, I., Bols, P.E.J., 2012. Endocrine-disrupting chemicals in human follicular fluid impair in vitro oocyte developmental competence. Hum. Reprod. 27, 1025-1033. doi:10.1093/humrep/der448

Petrulis, J.R., Hord, N.G., Perdew, G.H., 2000. Subcellular localization of the aryl hydrocarbon receptor is modulated by the immunophilin homolog hepatitis B virus $\mathrm{X}$ associated protein 2. J. Biol. Chem. 275, 37448-37453. doi:10.1074/jbc.M006873200

Pocar, P., Brevini, T. A. L., Antonini, S., Gandolfi, F., 2006. Cellular and molecular mechanisms mediating the effect of polychlorinated biphenyls on oocyte in vitro maturation. Reprod. Toxicol. 22, 242-249. doi:10.1016/j.reprotox.2006.04.023

Podratz, P.L., Filho, V.S.D., Lopes, P.F.I., Sena, G.C., Matsumoto, S.T., Samoto, V.Y., Takiya, C.M., Miguel, E.D.C., Silva, I.V., Graceli, J.B., 2012. Tributyltin Impairs the Reproductive Cycle in Female Rats. J. Toxicol. Environ. Heal. Part A 75, 1035-1046. doi:10.1080/15287394.2012.697826

Poland, A., Knutson, J.C., 1982. 2,3,7,8-Tetrachlorodibenzo-P-Dioxin and Related Halogenated Aromatic Hydrocarbons: Examination of the Mechanism of Toxicity. Annu. Rev. Pharmacol. Toxicol. 22, 517-554.

doi:10.1146/annurev.pa.22.040182.002505

Prizant, H., Gleicher, N., Sen, A., 2014. Androgen actions in the ovary: balance is key. J. Endocrinol. 222, R141-R151. doi:10.1530/JOE-14-0296

Qatanani, M., Zhang, J., Moore, D.D., 2005. Role of the constitutive androstane receptor in xenobiotic-induced thyroid hormone metabolism. Endocrinology 146, 9951002. doi:10.1210/en.2004-1350

Qiu, L., Zhang, X., Zhang, X., Zhang, Y., Gu, J., Chen, M., Zhang, Z., Wang, X., Wang, S.L., 2013. Sertoli cell is a potential target for perfluorooctane sulfonate-induced reproductive dysfunction in male mice. Toxicol. Sci. 135, 229-240. 
Rajapakse, N., Silva, E., Kortenkamp, A., 2002. Combining xenoestrogens at levels below individual no-observed-effect concentrations dramatically enhances steroid hormone action. Environ. Health Perspect. 110, 917-921. doi:10.1289/ehp.02110917

Raun Andersen, H., Vinggaard, A.M., Høj Rasmussen, T., Gjermandsen, I.M., Cecilie Bonefeld-Jørgensen, E., 2002. Effects of Currently Used Pesticides in Assays for Estrogenicity, Androgenicity, and Aromatase Activity in Vitro. Toxicol. Appl. Pharmacol. 179, 1-12. doi:10.1006/taap.2001.9347

Rey, R., Lukas-Croisier, C., Lasala, C., Bedecarrás, P., 2003. AMH/MIS: What we know already about the gene, the protein and its regulation. Mol. Cell. Endocrinol. 211, 21-31. doi:10.1016/j.mce.2003.09.007

Richards, J.S., Ireland, J.J., Rao, M.C., Bernath, G.A., Midgley, A.R., Reichert, L.E.O.E., 1976. Ovarian Follicular Development in the Rat: Hormone Receptor Regulation by Estradiol, Follicle Stimulating Hormone and Luteinizing Hormone. Endocrinology 99, 1562-1570. doi:10.1210/endo-99-6-1562

Richburg, J.H., Boekelheide, K., 1996. Mono-(2-ethylhexyl) phthalate rapidly alters both Sertoli cell vimentin filaments and germ cell apoptosis in young rat testes. Toxicol. Appl. Pharmacol. 137, 42-50. doi:S0041-008X(96)90055-1 [pii] $\ln 10.1006 /$ taap.1996.0055

Richburg, J.H., Nañez, A., Gao, H., 1999. Participation of the Fas-signaling system in the initiation of germ cell apoptosis in young rat testes after exposure to mono-(2ethylhexyl) phthalate. Toxicol. Appl. Pharmacol. 160, 271-278. doi:10.1006/taap.1999.8786\rS0041-008X(99)98786-0 [pii]

Rockett, J.C., Lynch, C.D., Buck, G.M., 2003. Biomarkers for Assessing Reproductive Development and Health: Part 1--Pubertal Development. Environ. Health Perspect. 112, 105-112. doi:10.1289/ehp.6265

Ronnback, C., de Rooij, D.G., 1994. Effects of 3,3',4,4'-tetrachlorobiphenyl on foetal germ cells in two mouse strains after repeated treatment of the dams during and after pregnancy. Pharmacol. Toxicol. 74, 287-293.

Roseweir, A. K., Millar, R.P., 2009. The role of kisspeptin in the control of gonadotrophin secretion. Hum. Reprod. Update 15, 203-212. doi:10.1093/humupd/dmn058

Rubin, B.S., 2011. Bisphenol A: An endocrine disruptor with widespread exposure and multiple effects. J. Steroid Biochem. Mol. Biol. 127, 27-34. doi:10.1016/j.jsbmb.2011.05.002

Rudel, R.A., Perovich, L.J., 2010. Endocrine disrupting chemicals in indoor and outdoor air. Crafts 43, 170-181. doi:10.1016/j.atmosenv.2008.09.025.Endocrine

Saitoh, M., Yanase, T., Morinaga, H., Tanabe, M., Mu, Y.M., Nishi, Y., Nomura, M., Okabe, T., Goto, K., Takayanagi, R., Nawata, H., 2001. Tributyltin or triphenyltin inhibits aromatase activity in the human granulosa-like tumor cell line KGN. Biochem. Biophys. Res. Commun. 289, 198-204. doi:10.1006/bbrc.2001.5952

Saunders, P.T., Majdic, G., Parte, P., Millar, M.R., Fisher, J.S., Turner, K.J., Sharpe, R.M., 1997. Fetal and perinatal influence of xenoestrogens on testis gene expression. 
Adv. Exp. Med. Biol. 424, 99-110.

Schug, T.T., Janesick, A., Blumberg, B., Heindel, J.J., 2011. Endocrine disrupting chemicals and disease susceptibility. J. Steroid Biochem. Mol. Biol. 127, 204-215. doi:10.1016/j.jsbmb.2011.08.007

Seo, J.S., Lee, Y.M., Jung, S.O., Kim, I.C., Yoon, Y.D., Lee, J.S., 2006. Nonylphenol modulates expression of androgen receptor and estrogen receptor genes differently in gender types of the hermaphroditic fish Rivulus marmoratus. Biochem. Biophys. Res. Commun. 346, 213-223. doi:10.1016/j.bbrc.2006.05.123

Shi, Z., Ding, L., Zhang, H., Feng, Y., Xu, M., Dai, J., 2009. Chronic exposure to perfluorododecanoic acid disrupts testicular steroidogenesis and the expression of related genes in male rats. Toxicol. Lett. 188, 192-200. doi:10.1016/j.toxlet.2009.04.014

Shih, I.M., Wang, T.L., 2007. Notch signaling, gamma-secretase inhibitors, and cancer therapy. Cancer Res. 67, 1879-1882. doi:10.1158/0008-5472.CAN-06-3958

Short, R. V., 1962. Steroids in the follicular fluid and the corpus luteum of the mare. A 'two-cell type' theory of ovarian steroid synthesis. J. Endocrinol. 24, 59-63.

Silva, E., Rajapakse, N., Kortenkamp, A., 2002. Something from "nothing" - Eight weak estrogenic chemicals combined at concentrations below NOECs produce significant mixture effects. Environ. Sci. Technol. 36, 1751-1756. doi:10.1021/es0101227

Silveira, L.F.G., Teles, M.G., Trarbach, E.B., Latronico, A.C., 2010. Role of kisspeptin/GPR54 system in human reproductive axis. Front. Horm. Res. 39, 13-24. doi:10.1159/000312689

Simpson, E.R., Mahendroo, M.S., Means, G.D., Kilgore, M.W., Hinshelwood, M.M., Graham-lorence, S., Amarneh, B., Ito, Y., Fisher, C.R., Michael, M.D., Mendelson, C.R., Bulun, S.E., 1994. Aromatase Cytochrome P450, The Enzyme Responsible for Estrogen Biosynthesis. Endocr. Rev. 15, 342-355. doi:10.1210/edrv-15-3-342

Siu, E.R., Mruk, D.D., Porto, C.S., Cheng, C.Y., 2009. Cadmium-induced testicular injury. Toxicol. Appl. Pharmacol. 238, 240-249. doi:10.1016/j.taap.2009.01.028

Sobarzo, C.M., Lustig, L., Ponzio, R., Denduchis, B., 2006. Effect of di-(2-ethylhexyl) phthalate on $\mathrm{N}$-cadherin and catenin protein expression in rat testis. Reprod. Toxicol. 22, 77-86. doi:10.1016/j.reprotox.2006.02.004

Stasenko, S., Bradford, E.M., Piasek, M., Henson, M.C., Varnai, V.M., Jurasović, J., Kušec, V., 2010. Metals in human placenta: Focus on the effects of cadmium on steroid hormones and leptin. J. Appl. Toxicol. 30, 242-253. doi:10.1002/jat.1490

Staudinger, J.L., Goodwin, B., Jones, S.A., Hawkins-Brown, D., MacKenzie, K.I., LaTour, A., Liu, Y., Klaassen, C.D., Brown, K.K., Reinhard, J., Willson, T.M., Koller, B.H., Kliewer, S.A., 2001. The nuclear receptor PXR is a lithocholic acid sensor that protects against liver toxicity. Proc. Natl. Acad. Sci. U. S. A. 98, 3369-74. doi:10.1073/pnas.051551698

Stewart, P.M., Boulton, A., Kumar, S., Clark, P.M., Shackleton, C.H.L., 1999. Cortisol metabolism in human obesity: impaired cortisone-->cortisol conversion in subjects with central adiposity. J. Clin. Endocrinol. Metab. 84, 1022-1027. 
doi:10.1210/jcem.84.3.5538

Stouder, C., Paoloni-Giacobino, A., 2011. Specific transgenerational imprinting effects of the endocrine disruptor methoxychlor on male gametes. Reproduction 141, 207-216. doi:10.1530/REP-10-0400

Svechnikov, K., Izzo, G., Landreh, L., Weisser, J., Sder, O., 2010. Endocrine disruptors and leydig cell function. J. Biomed. Biotechnol. 2010. doi:10.1155/2010/684504

Takayanagi, S., Tokunaga, T., Liu, X., Okada, H., Matsushima, A., Shimohigashi, Y., 2006. Endocrine disruptor bisphenol A strongly binds to human estrogen-related receptor $\gamma(E R R \gamma)$ with high constitutive activity. Toxicol. Lett. 167, 95-105. doi:10.1016/j.toxlet.2006.08.012

Themmen, A.P.N., Themmen, A.P.N., 2009. Anti-Mullerian Hormone Inhibits Initiation of Primordial Follicle Growth in the Mouse Ovary. Bibliothek 143, 1076 -1084.

Uzumcu, M., Kuhn, P.E., Marano, J.E., Armenti A.E., Passantino, L., 2006. Early postnatal methoxychlor exposure inhibits folliculogenesis and stimulates anti-Mullerian hormone production in the rat ovary. J. Endocrinol. 191, 549-558. doi:10.1677/joe.1.06592

Vandenberg, L.N., 2014. Non-monotonic dose responses in studies of endocrine disrupting chemicals: Bisphenol a as a case study. Dose-Response 12, 259-276. doi:10.2203/dose-response.13-020.Vandenberg

Vandenberg, L.N., Colborn, T., Hayes, T.B., Heindel, J.J., Jacobs, D.R., Lee, D.H., Myers, J.P., Shioda, T., Soto, A. M., Vom Saal, F.S., Welshons, W. V, Zoeller, R.T., 2013. Regulatory decisions on endocrine disrupting chemicals should be based on the principles of endocrinology. Reprod. Toxicol. 38, 1-15. doi:DOI 10.1016/j.reprotox.2013.02.002

Vandenberg, L.N., Colborn, T., Hayes, T.B., Heindel, J.J., Jacobs, D.R., Lee, D.H., Shioda, T., Soto, A.M., Vom Saal, F.S., Welshons, W. V., Zoeller, R.T., Myers, J.P., 2012. Hormones and endocrine-disrupting chemicals: Low-dose effects and nonmonotonic dose responses. Endocr. Rev. 33, 378-455. doi:10.1210/er.2011-1050

Vandenberg, L.N., Maffini, M. V., Sonnenschein, C., Rubin, B.S., Soto, A.M., 2009. Bisphenol-A and the great divide: A review of controversies in the field of endocrine disruption. Endocr. Rev. 30, 75-95. doi:10.1210/er.2008-0021

Vanorny, D. A., Prasasya, R.D., Chalpe, A.J., Kilen, S.M., Mayo, K.E., 2014. Notch signaling regulates ovarian follicle formation and coordinates follicular growth. Mol. Endocrinol. 28, 499-511. doi:10.1210/me.2013-1288

Vom Saal, F., Hughs, C., 2005. An Extensive New Literature Concerning Low-Dose Effects of Bisphenol-A Shows the Need for a New Risk Assessment. Environ. Health Perspect. 113, 926-933. doi:10.1289/ehp.7713

Wan, H.T., Zhao, Y.G., Wong, M.H., Lee, K.F., Yeung, W.S.B., Giesy, J.P., Wong, C.K.C., 2011. Testicular signaling is the potential target of perfluorooctanesulfonatemediated subfertility in male mice. Biol. Reprod. 84, 1016-1023. doi:10.1095/biolreprod.110.089219

Wang, H.X., Tong, D., El-Gehani, F., Tekpetey, F.R., Kidder, G.M., 2009. Connexin expression and gap junctional coupling in human cumulus cells: Contribution to embryo 
quality. J. Cell. Mol. Med. 13, 972-984. doi:10.1111/j.1582-4934.2008.00373.x

Wang, J., Sun, B., Hou, M., Pan, X., Li, X., 2012. The environmental obesogen bisphenol A promotes adipogenesis by increasing the amount of $11 \beta$-hydroxysteroid dehydrogenase type 1 in the adipose tissue of children. Int. J. Obes. 999-1005. doi:10.1038/ijo.2012.173

Wang, R.Y., Needham, L.L., Barr, D.B., 2005. Effects of Environmental Agents on the Attainment of Puberty: Considerations When Assessing Exposure to Environmental Chemicals in the National Children's Study. Environ. Health Perspect. 113, 1100-1107. doi:10.1289/ehp.7615

Wong, E.W.P., Cheng, C.Y., 2011. Impacts of environmental toxicants on male reproductive dysfunction. Trends Pharmacol. Sci. 32, 290-299. doi:10.1016/j.tips.2011.01.001

Wuttke, W., Jarry, H., Seidlova-wuttke, D., 2010. Definition , classification and mechanism of action of endocrine disrupting chemicals. Hormones 9, 9-15. doi:10.14310/horm.2002.1252

Xi, W., Lee, C.K.F., Yeung, W.S.B., Giesy, J.P., Wong, M.H., Zhang, X., Hecker, M., Wong, C.K.C., 2011. Effect of perinatal and postnatal bisphenol A exposure to the regulatory circuits at the hypothalamus-pituitary-gonadal axis of CD-1 mice. Reprod. Toxicol. 31, 409-417. doi:10.1016/j.reprotox.2010.12.002

Xu, Y.P., Chedrese, P.J., Thacker, P. A., 1995. Growth hormone amplifies insulin-like growth factor I induced progesterone accumulation and P450scc mRNA expression. Mol. Cell. Endocrinol. 111, 199-206. doi:10.1016/0303-7207(95)03569-S

Yang, M., Chen, M., Wang, J., Xu, M., Sun, J., Ding, L., LV., X., Ma, Q., Bi, Y., Liu, R., Hong, J., Ning, G., 2016. Bisphenol A promotes adiposity and inflammation in a nonmonotonic dose-response way in five-week old male and female C57BL/6J mice fed a low-calorie diet. Endocrinology en.2015-1926. doi:10.1210/en.2015-1926

Yao, P. L., Lin, Y. C., Richburg, J.H., 2012. Mono-(2-Ethylhexyl) Phthalate (MEHP) Promotes Invasion and Migration of Human Testicular Embryonal Carcinoma Cells. Biol. Reprod. 86, 160-160. doi:10.1095/biolreprod.111.097295

Yoon, H. G., Choi, Y., Cole, P. A., Wong, J., 2005. Reading and function of a histone code involved in targeting corepressor complexes for repression. Mol. Cell. Biol. 25, 324-335. doi:10.1128/MCB.25.1.324-335.2005

Zhang, L.J., Pan, B., Chen, B., Zhang, X.F., Liang, G.J., Feng, Y.N., Wang, L.Q., Ma, J.M., Li, L., Shen, W., 2012. Expression and epigenetic dynamics of transcription regulator Lhx8 during mouse oogenesis. Gene 506, 1-9. doi:10.1016/j.gene.2012.06.093

Zhang, T., Li, L., Qin, X. S., Zhou, Y., Zhang, X. F., Wang, L. Q., De Felici, M., Chen, H., Qin, G. Q., Shen, W., 2014. Di-(2-ethylhexyl) phthalate and bisphenol A exposure impairs mouse primordial follicle assembly in vitro. Environ. Mol. Mutagen. 55, 343353. doi:10.1002/em.21847

Zhao, B., Hu, G.X., Chu, Y., Jin, X., Gong, S., Akingbemi, B.T., Zhang, Z., Zirkin, B.R., Ge, R.S., 2010. Inhibition of human and rat $3 \beta$-hydroxysteroid dehydrogenase and $17 \beta$-hydroxysteroid dehydrogenase 3 activities by perfluoroalkylated substances. Chem. 
Biol. Interact. 188, 38-43. doi:10.1016/j.cbi.2010.07.001

Zhao, B., Lian, Q., Chu, Y., Hardy, D.O., Li, X.K., Ge, R.S., 2011. The inhibition of human and rat 11ß-hydroxysteroid dehydrogenase 2 by perfluoroalkylated substances. J. Steroid Biochem. Mol. Biol. 125, 143-147. doi:10.1016/j.jsbmb.2010.12.017

Zoeller, T.R., 2010. Environmental chemicals targeting thyroid. Hormones 9, 28-40. doi:10.14310/horm.2002.1250 


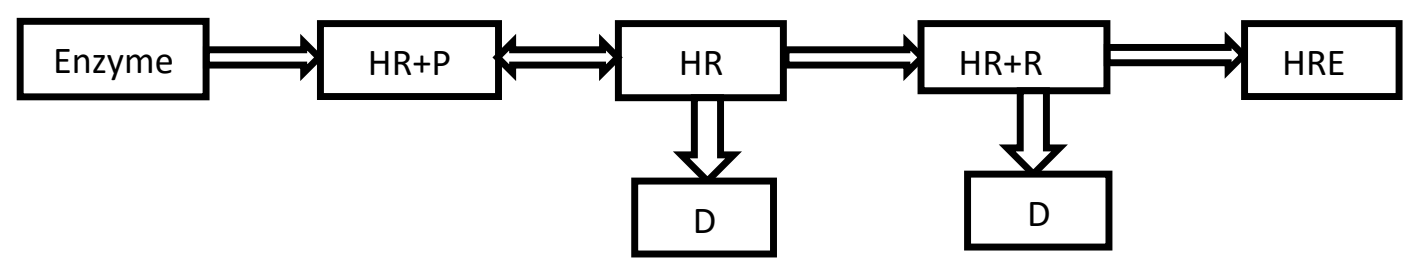

Figure 1: Effects of EDCs on hormone action at different level.

Enzyme responsible for hormone synthesis, HR- hormone, P- hormone binding protein, $\mathrm{R}$ - receptor, D- degradation of hormone and its receptor, HRE- hormone response element.

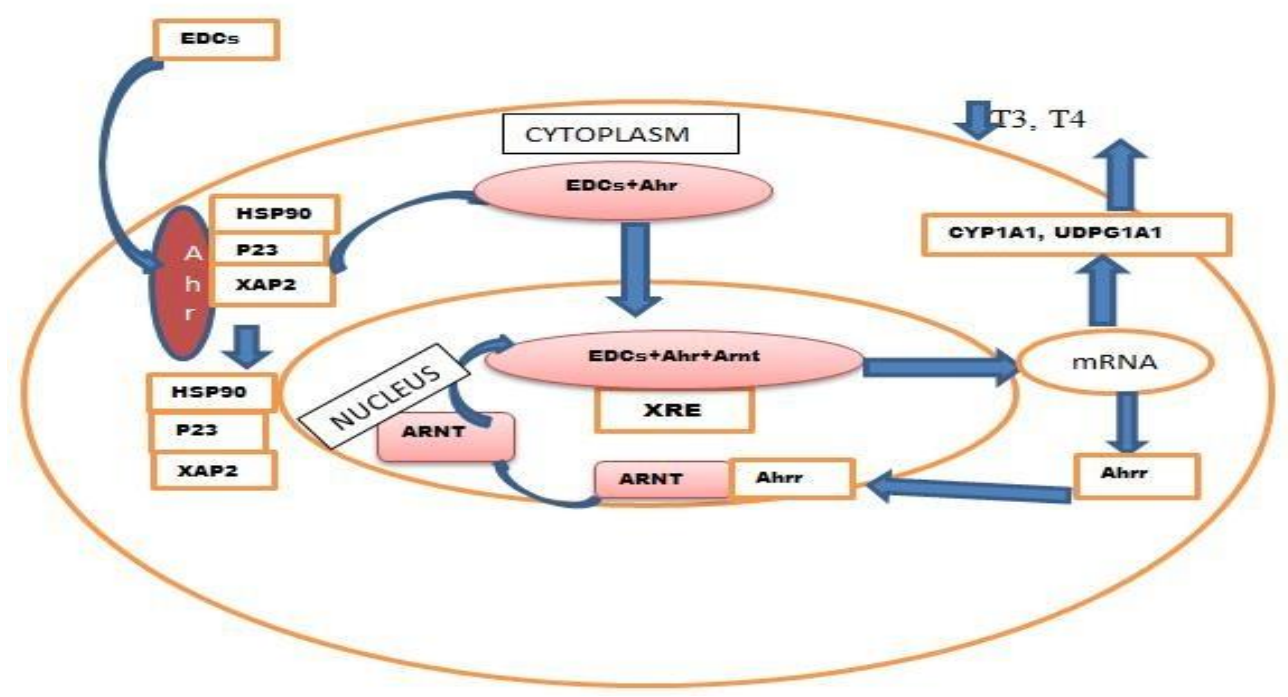

Figure 2: Summary of molecular mechanism of EDCs binding with Ahr-. The binding of EDCs with Ahr leads to translocation of Ahr receptor to the nucleus from cytoplasm following dissociation of chaperons, forming Ahr-Arnt complex. This complex binds with XRE (xenobiotic response element) causing induction of CYPs enzyme, enhancing metabolism of endogenous hormone. 

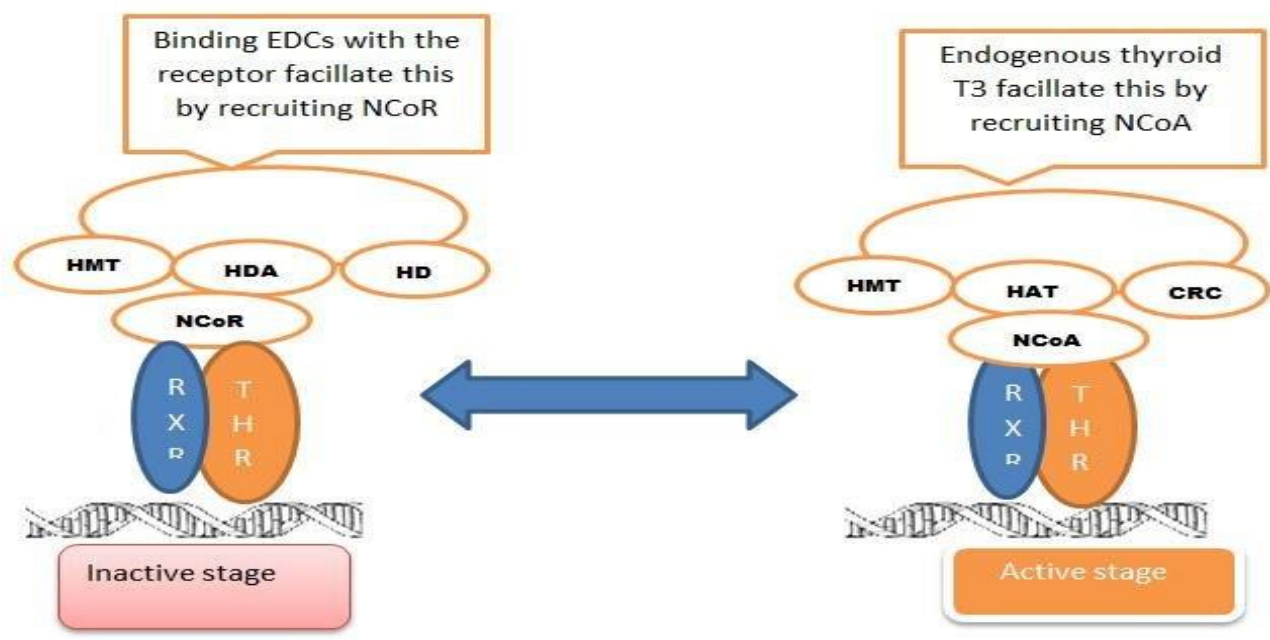

Figure 3: EDCs affecting dynamic state of receptor. Unliganded thyroid receptor resides in nucleus in inactive state by recruiting $\mathrm{NCoR}$ and thyroid binding facillates active stage by recruiting NCoA. Binding of EDCs with thyroid receptor induced conformational changes by recruiting $\mathrm{NCoR}$ facilitating its inactive stage.

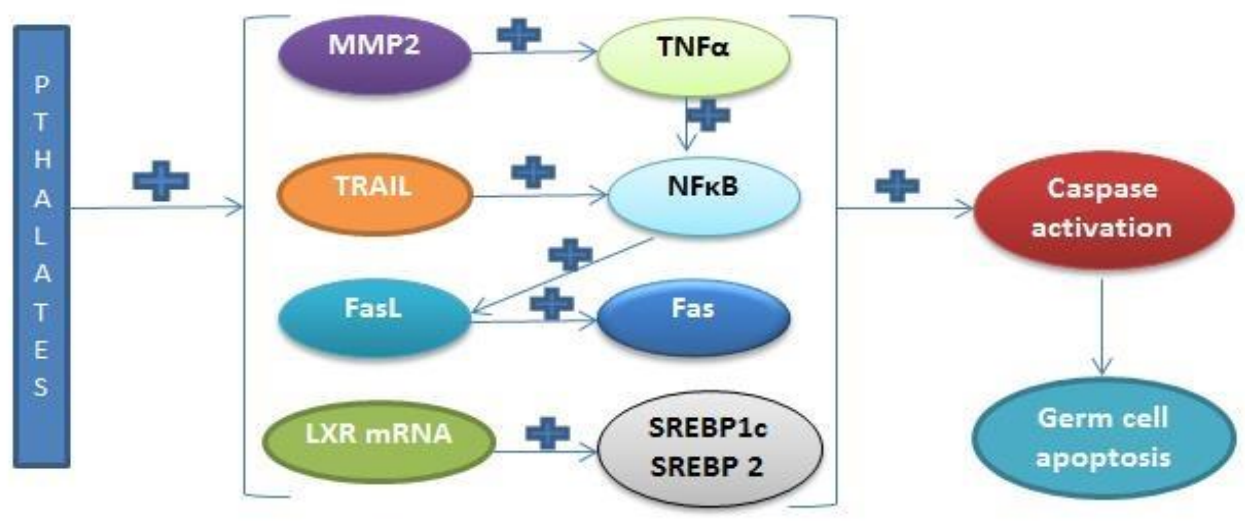

Figure 4: Mechanism of phthalates causing germ cell apoptosis in fetus. Phthalates exposure at tissue level causes activation of caspase pathway which lead to apoptosis of germ cell through interaction and activation of receptor and gene at cellular level. 


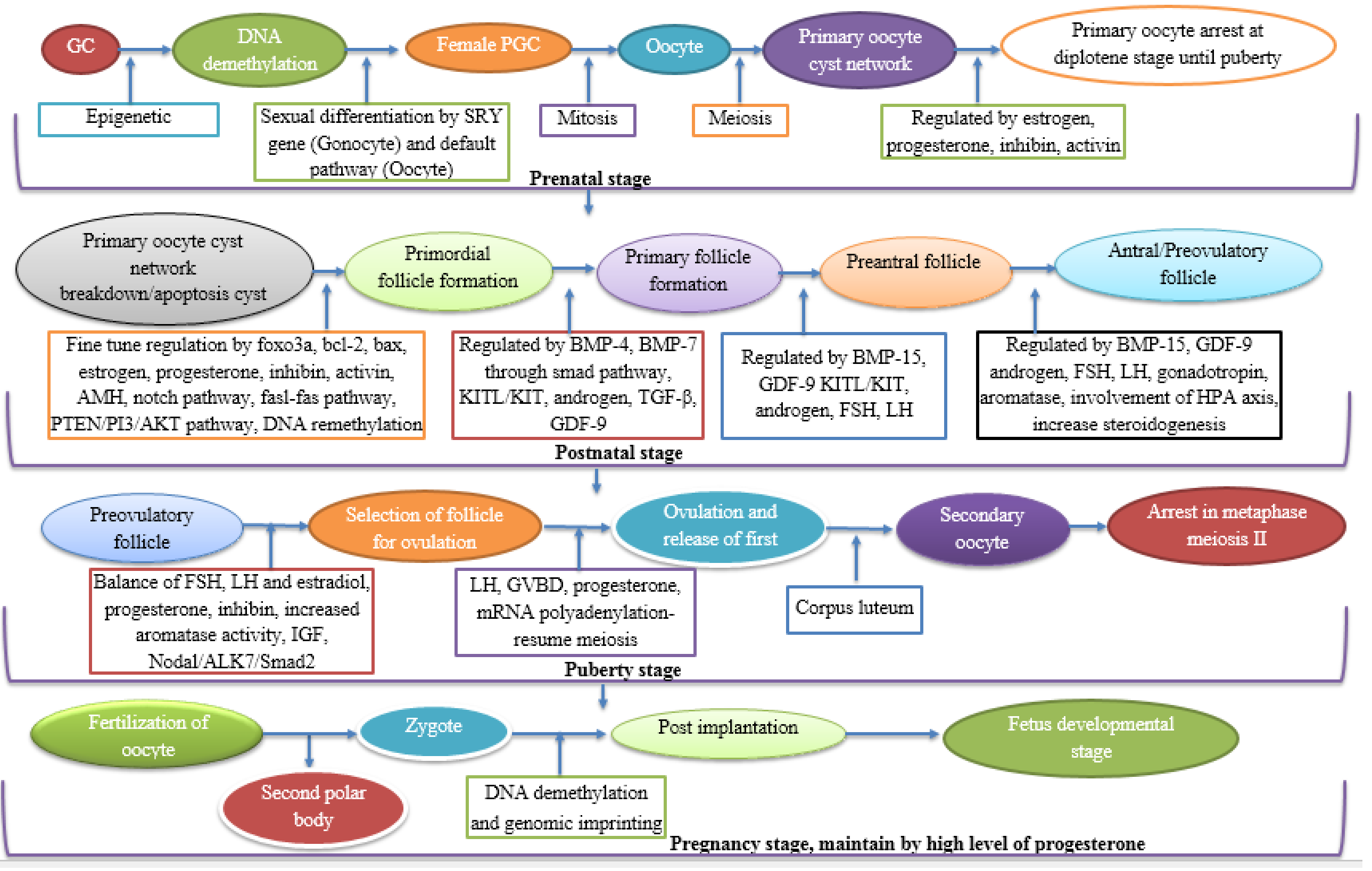


Figure 5: Life stage development of germ cell and the possible targets of EDCs. The germ cell, basis of future sexual life or transgenerational development, development of oocyte from germ cell starts at embryo stage. Exposure of EDCs to pregnant mother (F0) may cross placental barrier and affect embryonic germ cell in fetus (F1). This could lead to alteration in oocyte quality required for fertilization and transgenerational fetus development (F2). Every stage of development of germ cell to high quality oocyte, demands fine tune balance of endogenous level and interaction pathway. Categorizing development of germ in stages provides information on susceptible targets of EDCs during the journey of germ cell of fetus (F1) residing in mother embryo (F0) to high quality of oocyte, for development of transgenerational fetus (F2). 


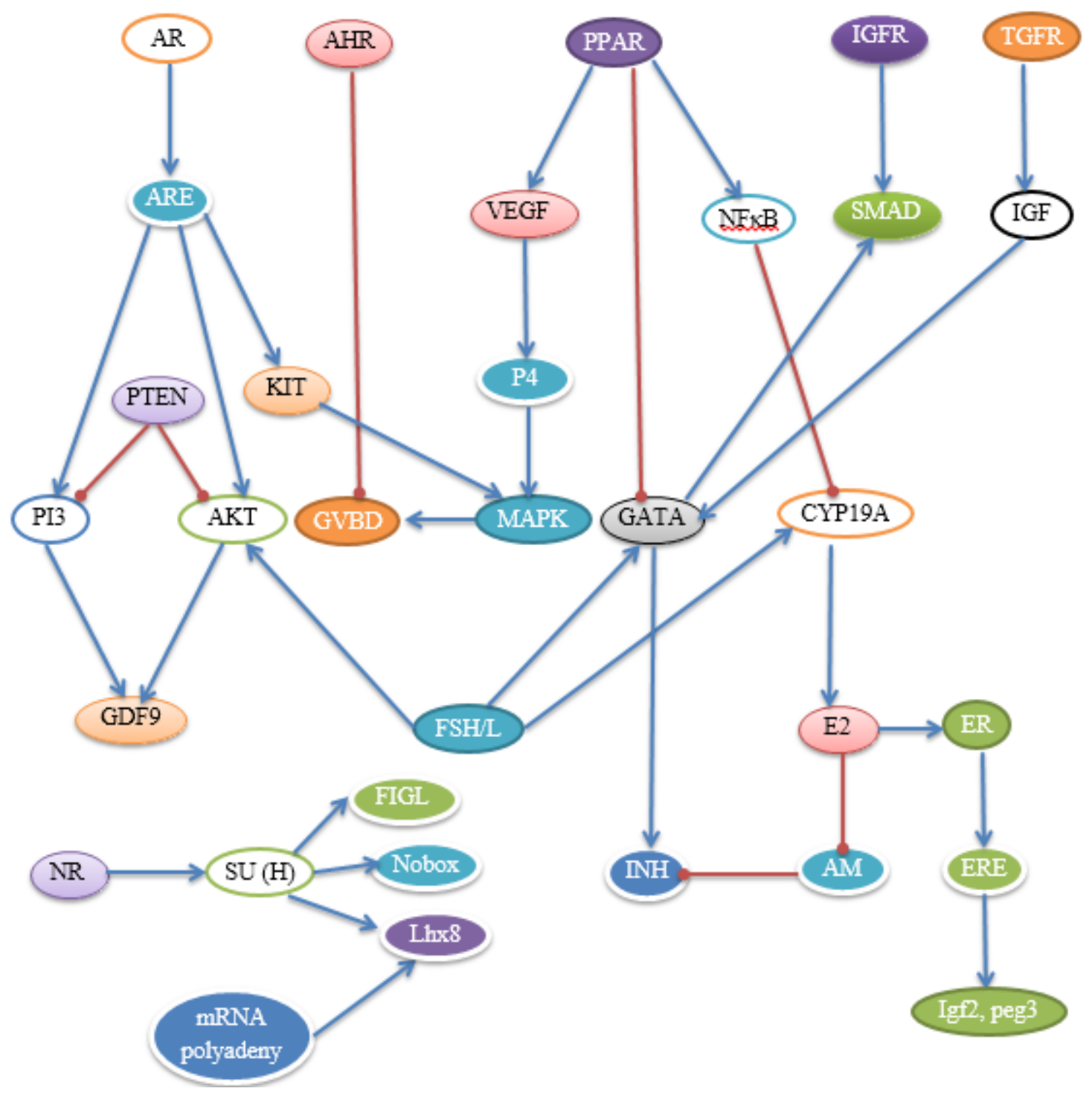

Figure 6: Signaling pathway for life stage development of germ cell to zygote. The figure depicts the different signaling pathways initiation via binding of endogenous molecule with receptors, which leads to inhibitory and stimulatory effect on signaling molecule following physiological demand for the development of germ cell into mature oocyte. 
EDCs

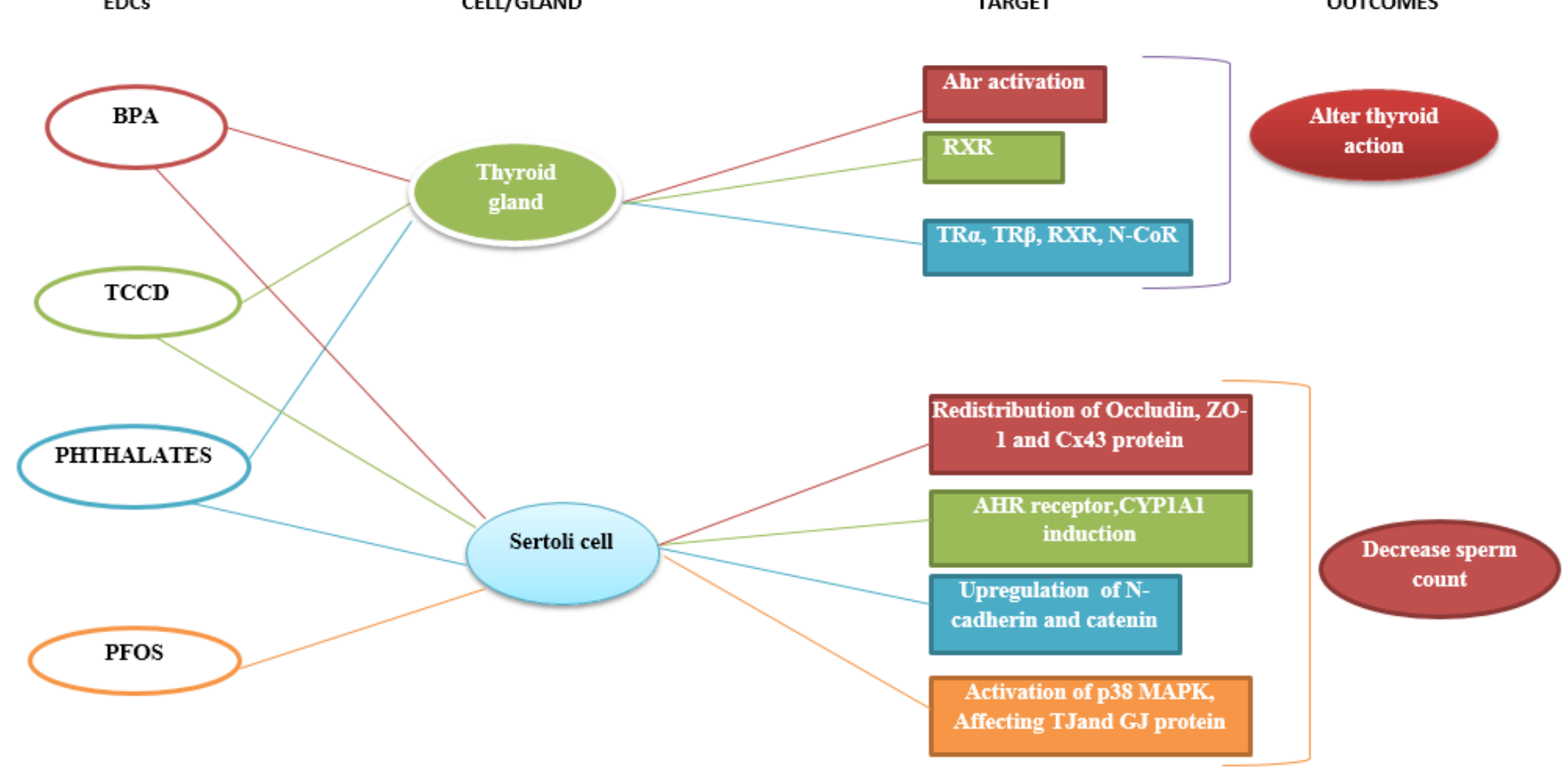

BPA- - , TCDD- - , Phthalates- $-\frac{1}{\square}$ PFOS-

Figure 7: Endocrine disruptor's classification on the basis of mode of action for selected chemicals (BPA, TCDD, Phthalates and PFOS), with different targets on thyroid and sertoli cell with common adverse effect in respective cell. 


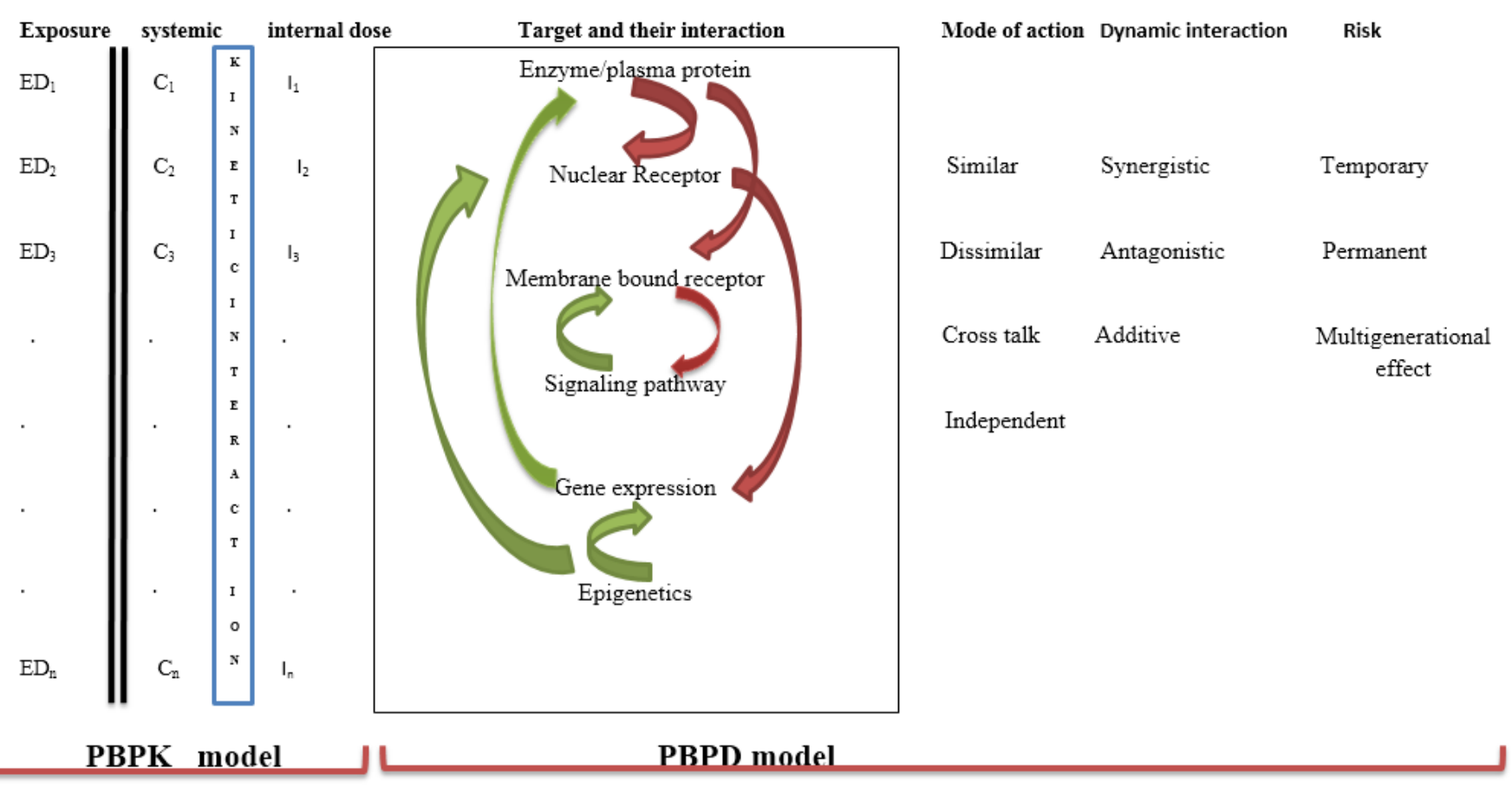

PBPK/PD Risk assessment model

Figure 8: Conceptual model of PBPK/PD in assessing risk for chemical mixture (ED- endocrine disruptor exposure, $\mathrm{C}$ - concentration of ED in systemic circulation, I- concentration of ED in target organ or tissue, DI- dynamic interaction)

PBPK usually well describes time course of tissue level exposure of chemical relating environmental exposure by including their absorption, distribution, metabolism and excretion. At cellular level, the interaction of chemicals with endogenous biomolecules and their pathways which are interrelated with each other results in initiation of an event that could lead to adverse outcomes which can be describe by PBPD model. The integrated PBPK/PD can describe the kinetic as well as dynamic interaction of EDCs giving time course effect of chemicals. 


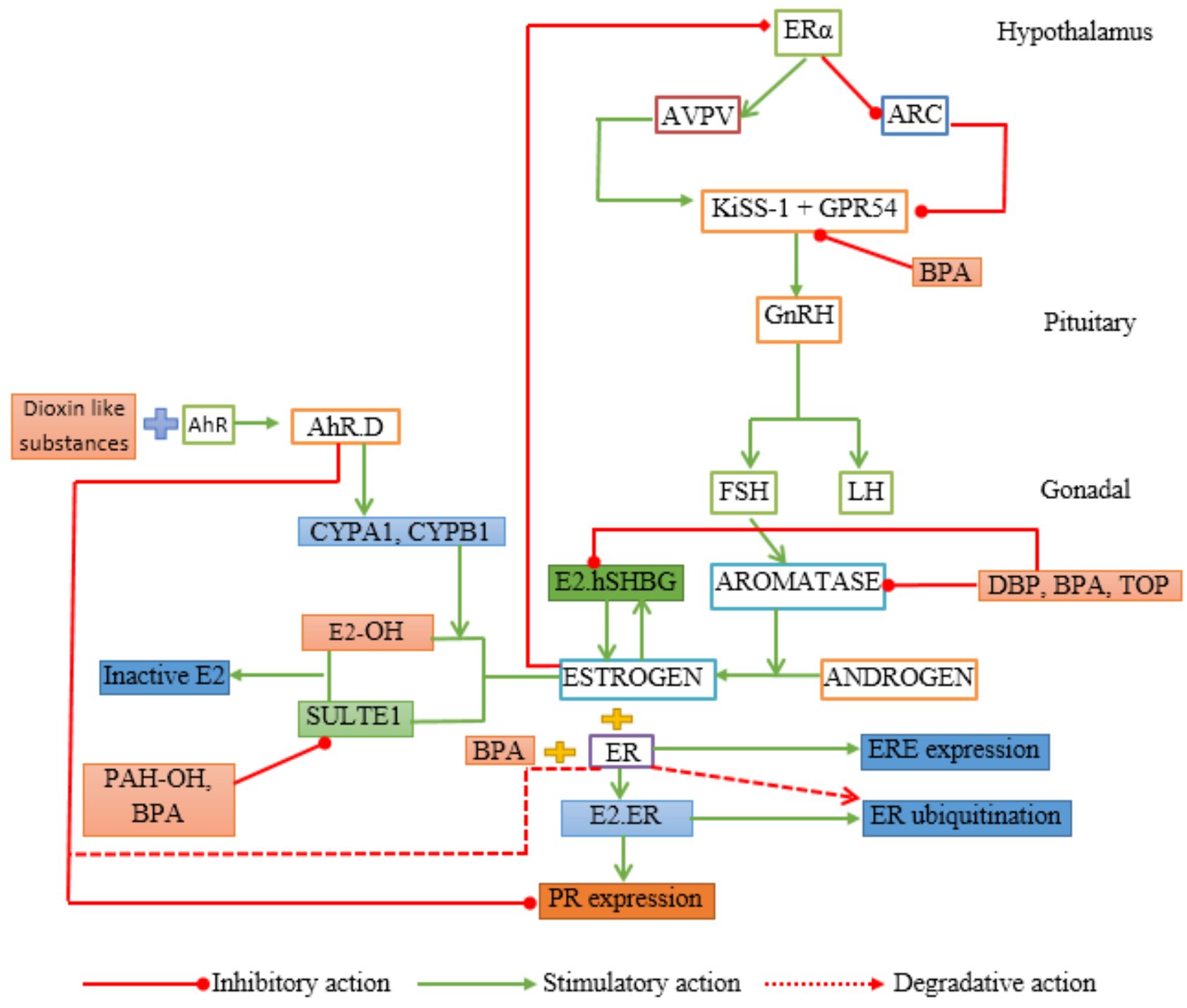

Figure 9: Schematic model for studying mixture effect in dynamic level.

This figure contains the hypothetical mixture model of characterizing risk through detail understanding of mode of chemicals' interaction with different biological components of the HPG pathways describing multiple mechanisms. 
